\title{
Review \\ Hepatocellular Carcinoma: Molecular Pathogenesis and Therapeutic Advances
}

\author{
Blanca Cucarull ${ }^{1,+} \oplus^{\circ}$, Anna Tutusaus ${ }^{1,+}{ }^{\oplus}$, Patricia Rider ${ }^{1}$, Tania Hernáez-Alsina ${ }^{2}$, Carlos Cuño ${ }^{1}$, \\ Pablo García de Frutos $1,3\left(\right.$, Anna Colell ${ }^{1,4}\left(\mathbb{D}\right.$, Montserrat Marí ${ }^{1, *(1)}$ and Albert Morales $1,5, *(1)$
}

1 Department of Cell Death and Proliferation, IIBB-CSIC, IDIBAPS, 08036 Barcelona, Spain; blanca.cucarull@iibb.csic.es (B.C.); anna.tutusaus@iibb.csic.es (A.T.); rider@clinic.cat (P.R.); carlos.cuno@iibb.csic.es (C.C.); pablo.garcia@iibb.csic.es (P.G.d.F.); anna.colell@iibb.csic.es (A.C.)

2 Digestive Unit, Hospital San Pedro, Rioja Salud, 26006 Logroño, Spain; thernaez@riojasalud.es

3 Unidad Asociada (IMIM), IIBB-CSIC, CIBERCV, IDIBAPS, 08036 Barcelona, Spain

4 Network Center for Biomedical Research in Neurodegenerative Diseases (CIBERNED), 08036 Barcelona, Spain

5 Barcelona Clinic Liver Cancer Group, Liver Unit, Hospital Clínic of Barcelona, University of Barcelona, CIBEREHD, IDIBAPS, 08036 Barcelona, Spain

* Correspondence: monmari@clinic.cat (M.M.); amorales@clinic.cat (A.M.); Tel.: +34-932558314 (M.M. \& A.M.)

+ All authors have contributed equally to this work.

Citation: Cucarull, B.; Tutusaus, A.; Rider, P.; Hernáez-Alsina, T.; Cuño, C.; García de Frutos, P.; Colell, A.; Marí, M.; Morales, A. Hepatocellular Carcinoma: Molecular Pathogenesis and Therapeutic Advances. Cancers 2022, 14, 621. https://doi.org/ 10.3390/cancers14030621

Academic Editor: Hiroyuki Tsuchiya

Received: 23 December 2021

Accepted: 22 January 2022

Published: 26 January 2022

Publisher's Note: MDPI stays neutral with regard to jurisdictional claims in published maps and institutional affiliations.

Copyright: () 2022 by the authors Licensee MDPI, Basel, Switzerland. This article is an open access article distributed under the terms and conditions of the Creative Commons Attribution (CC BY) license (https:// creativecommons.org/licenses/by/ $4.0 /)$.
Simple Summary: Patients with unresectable hepatocellular carcinoma (HCC), the most common primary tumor of the liver, have poor prognosis and are increasing worldwide. The recent approval of several novel therapies for HCC was long expected, and it will make physician decision-making more challenging. The molecular mechanisms triggered during chronic liver diseases and the cellular cross-talk established with liver cells influence HCC growth and may reduce immune control, making this knowledge relevant to help with clinical decisions. This review analyzes these issues and points to relevant topics for future research.

\begin{abstract}
Hepatocellular carcinoma (HCC), the most common form of liver cancer, continues to be a serious medical problem with poor prognosis, without major therapeutic improvement for years and increasing incidence. Fortunately, advances in systemic treatment options are finally arriving for HCC patients. After a decade of sorafenib as a standard therapy for advanced HCC, several tyrosine kinase inhibitors (TKIs), antiangiogenic antibodies, and immune checkpoint inhibitors have reached the clinic. Although infections by hepatitis B virus and hepatitis C virus remain principal factors for HCC development, the rise of non- alcoholic steatohepatitis from diabetes mellitus or metabolic syndrome is impeding HCC decline. Knowledge of specific molecular mechanisms, based on the etiology and the HCC microenvironment that influence tumor growth and immune control, will be crucial for physician decision-making among a variety of drugs to prescribe. In addition, markers of treatment efficacy are needed to speed the movement of patients towards other potentially effective treatments. Consequently, research to provide scientific data for the evidence-based management of liver cancer is guaranteed in the coming years and discussed here.
\end{abstract}

Keywords: liver cancer; molecular therapies; immune checkpoint inhibitors; tyrosine kinase inhibitors; tumor microenvironment

\section{Hepatocellular Carcinoma \\ 1.1. Epidemiology}

Liver cancer is the sixth-most-frequent neoplasm and the third-most-frequent cause of cancer-related death, with approximately 900,000 new cases and 830,000 deaths in 2020 [1,2]. Among liver cancers, hepatocellular carcinoma (HCC) accounts for around 75\% of primary liver tumors [3]. HCC develops in a context of chronic liver disease, and in most cases incidence rates of HCC among men are 2- to 4-fold higher than rates among 
women [4]. Common risk factors are chronic infection with hepatitis B virus (HBV) and aflatoxin B1 exposure in eastern Asia and sub-Saharan Africa [5], while, in Europe, Japan, and North America, the main risk factors are hepatitis $\mathrm{C}$ virus (HCV) and alcohol use [6]. Unfortunately, the prevalence of metabolic risk factors for HCC, including metabolic syndrome, obesity, type II diabetes, and nonalcoholic fatty liver disease (NAFLD), are emerging as HCC causes and may jointly become the leading cause of HCC worldwide in the near future, while incidence due to HBV or HCV will likely decline [4]. These causes, together with tobacco and some dietary factors, such as high iron intake, also increase the risk of developing HCC [4].

The expected decline in virus-related HCC incidence is due to HBV vaccination programs, a successful public health strategy, and HCV treatment (interferon and directacting antivirals) that might reduce the risk of HCC development, particularly in patients with sustained viral response. Coffee consumption and statins use have also been linked to a decrease in HCC incidence [7,8].

\subsection{Molecular Pathogenesis \\ 1.2.1. Cellular Origin}

The cell of origin of HCC remains elusive, probably due to the heterogeneity of liver cancer within the same tumor and between different tumors [9]. Previous studies have suggested, as in numerous cancer types, that liver stem cells may be responsible for initiating HCC, but a transit-amplifying population or mature hepatocytes could also be responsible. Nonetheless, in contrast to most organs, the liver lacks a defined stem cell population for organ maintenance. Some preclinical murine models of HCC support the likelihood of mature hepatocytes, and not of progenitor cells, as the cellular source of HCC [10]. This transformation of hepatocytes can take place via a sequence of genetic alterations or through dedifferentiation into hepatocyte precursor cells, which then become HCC cells that express progenitor cell markers, or by transdifferentiation into biliary-like cells that give rise to intrahepatic cholangiocarcinoma [9], therefore suggesting extraordinary hepatocyte cell plasticity [11].

\subsubsection{Molecular Drivers}

About $70-80 \%$ of HCC develop in a context of cirrhosis that involves a complex multistep process [6]. In the cirrhotic liver, HCC starts with the presence of pre-cancerous cirrhotic nodules, called low-grade dysplastic nodules (LGDNs), that can transform into high-grade dysplastic nodules (HGDNs) and, in turn, into early-stage HCC and progress to advanced HCC [6]. Without underlying cirrhosis (20-30\% cases), HCC can develop mainly on a background of HBV infection or NASH [12,13] or, less frequently, adenomas [14].

HCC arises from the accumulation of somatic mutations and epigenomic alterations. While most of them occur in 'passenger' genes, a few of them are regarded as 'drivers' responsible for the activation of key signaling pathways leading to hepatocarcinogenesis [6,12]. In dysplastic nodules and established HCC, mutations of TERT promoter, which encodes the synthesis of telomere reverse transcriptase, are frequent (6\% in LGDNs, $20 \%$ in HGDNs, and 60\% in HCC) [15]. HBV can also induce insertional mutagenesis in TERT promoter, as well as adeno-associated virus type 2 (AAV2), although to a much shorter extent $[15,16]$. The WNT- $\beta$-catenin pathway is frequently activated in HCC due to mutations in AXIN1 and CTNNB1 (11-37\% cases) [17]. p53 inactivation and cell cycle control alterations (CDKN2A) are also common in HCC, especially in aflatoxin B1 exposure and HBV infection $[18,19]$. Furthermore, defects in chromatin remodeling complexes and epigenetic regulators are often found in $\mathrm{HCC}$, including mutations in the BRG1- or HRBM-associated factors (BAFs) and polybromo-associated BAF (PBAF) chromatin complex [13,15].

Receptor tyrosine kinase (RAS-RAF-MAPK) and phosphatidylinositol-3-kinase, Protein kinase $B$ and mammalian target of rapamycin (PI3K-AKT-mTOR) pathways are usually activated in HCC, owing to the amplification of regions that includes FGF19 (5\% tumors) and mutations in RPS6KA3 and RSK2 (5-9\% cases) [16,20]. 
Oxidative stress signaling pathway is also activated through activating mutations in nuclear factor erythroid 2-related factor 2 (NFE2L2 or NFR2) or the inactivation of Kelchlike ECH-associated protein 1 (KEAP1) [21]. DNA amplifications take place in chromosome regions 11q13 and 6p21, affecting the oncogene cyclin D1 (CCND1) and neoangiogenic vascular endothelial growth factor A (VEGFA) respectively, inducing the latter tumor proliferation through the secretion of macrophage-mediated hepatocyte growth factor (HGF) [22,23]. Unfortunately, most of the mutations in HCC occur in non-druggable pathways such as in the WNT- $\beta$-catenin, p53, or the TERT promoter, while those mutations located in more easily treatable targets are only present in a low percentage of patients, making it difficult to apply specific therapies [16,24]

\subsubsection{Molecular Classes}

Genomic, transcriptomic, and epigenomic profiling analyses have allowed the establishment of a molecular classification of HCC. Despite the fact that this classification is not used yet in clinical practice, it correlates with clinical features [25,26]. Two molecular subtypes have been identified: the proliferation class and the nonproliferation class $[27,28]$. Cell proliferation and survival pathways, such as PI3K-AKT-mTOR, RAS-MAPK and MET, chromosomal instability, TP53 inactivation, FGF19 and CCND1 amplifications, and $\alpha$-fetoprotein overexpression characterize the proliferation class. This proliferation class is associated with HBV infection and has a poor clinical outcome [29,30]. On the other hand, tumors that belong to the nonproliferation class often have an activation of CTNNB1 and more TERT promoter mutations. Transcriptionally, those tumors are similar to normal hepatocytes and are related to alcohol use and HCV infection etiologies and have better outcomes [13,31].

Tumor microenvironment (TME) is considered to play a fundamental role in all steps of carcinogenesis [32]. HCC has an inflammatory milieu due to viral hepatitis, alcohol abuse, and NAFLD or NASH. Immune cells, such as lymphocytes and macrophages, stellate cells, and endothelial cells interact with hepatocytes in the chronically inflamed liver [6,12]. According to this, HCCs that have high immune cell infiltration, activation of programmed cell death protein 1 (PD-1)/programmed cell death 1 ligand 1 (PD-L1), and activation of IFN $\gamma$ signaling pathway and granzyme B and perforin 1 expression could be grouped into an 'immune class' and constitute $30 \%$ of tumors. Two different subclasses can be found within the 'immune class', an adaptive $\mathrm{T}$ cell response can identify the 'active immune' subtype, whereas the 'exhausted subclass' exhibits TGF $\beta$-mediated immunosuppression and T cell exhaustion [33]. However, $25 \%$ of HCC have no immune cell infiltration.

\subsection{Surveillance}

Patients with HCC at early stages may benefit the most from surveillance, since the symptoms caused by HCC are often detected at advanced stages of the disease and, therefore, those patients are not eligible for curative treatment [6]. Survival benefits of HCC surveillance have been shown in several publications that include mathematical models, a clinical trial, and a meta-analysis of cohort studies [34-36]. Surveillance could be useful for patients with cirrhosis but preserved liver function (having more of $1.5 \%$ incidence of HCC per year), as well as patients who are candidates for liver transplant [37]. Patients with chronic HBV infection have different risk of developing HCC depending on their geographic region. Age, male sex, liver fibrosis, high viral replication, genotype $C$, and a family history of HCC also increase such risk [38]. While patients with chronic HCV infection and fibrosis should be enrolled in a surveillance program, patients who have developed NAFLD in the absence of cirrhosis are not eligible for surveillance, since the risk of HCC is likely to be rather low [13]. However, current information is limited and additional studies will be necessary to validate HCC risk in those patients.

Abdominal ultrasonography every six months is the preferred test for surveillance. It has a sensitivity of $60-80 \%$ and a specificity of more than $90 \%$ [39]. The most common 
serological tumor marker is $\alpha$-fetoprotein (AFP), although its sensitivity is around $60 \%$ [40], hardly appropriate for patients' screening.

Several recent studies have focused on evaluating extracellular vesicles, circulating tumor cells, cell-free DNA, and non-coding RNA as novel reliable biomarkers to improve sensitivity [41]. To date, liquid biopsy, as a source of blood-base biomarkers, is believed to be a very trustworthy instrument, and some of these new non-invasive tools will undoubtedly change HCC clinical management by providing more detailed individualized decisionmaking in patients, including prognostic outcome [41].

\subsection{Diagnosis}

Diagnostic algorithms based on nodule size and detection have been described elsewhere [42,43]. Imaging techniques allow the distinction of a pattern of hyperenhancement in the arterial phase and washout in venous or delayed phases on contrast-enhanced CT or MRI, as, during the malignant transformation of hepatocytes, benign lesions receive blood supply from the portal system, while malignant nodules are supplied from the hepatic artery in patients with cirrhosis [44]. Additionally, the use of immunohistochemical markers such as glypican 3 , heat shock protein 70 , glutamine synthetase, and clathrin heavy chain can increase accuracy at the time of diagnosis [45].

\subsection{Staging}

Most patients with HCC have concomitant liver disease. For this reason, the prognosis evaluation must include tumor stage, the degree of liver dysfunction, and performance status [13,42], along with treatment indication [46]. Besides more generic staging systems such as tumor, node, metastasis (TNM), specific systems for liver cancer has been described such as the Cancer of the Liver Italian Program (CLIP score) or the Hong Kong Liver Cancer (HKLC) staging system [47,48]. So far, the Barcelona Clinic Liver Cancer (BCLC) algorithm is the staging system most widely applied for HCC. Since 1999, when it was first introduced, it has been updated according to clinical data [49]. This staging system quantifies tumor burden depending on the number and size of lesions and the presence/absence of macrovascular tumor invasion (Figure 1). In addition, the Child-Pugh grade assesses liver function impairment, although it has limited predictive power $[43,50]$. The albumin-bilirubin (ALBI) score stratifies patients across BCLC stages, but its role in clinical decision-making or stratification in trials is yet to be defined [42,43].

High AFP serum levels are linked to a poorer prognosis. Some studies have described that increased AFP levels can predict the risk of tumor relapse after surgical resection [51] or response to loco-regional treatment and survival in HCC [52]. Vascular endothelial growth factor (VEGF), angiopoietin 2 (Ang2), or KIT may improve prognostic prediction, but these markers are still to be implemented on the individual assessment of a specific patient $[42,52]$. 


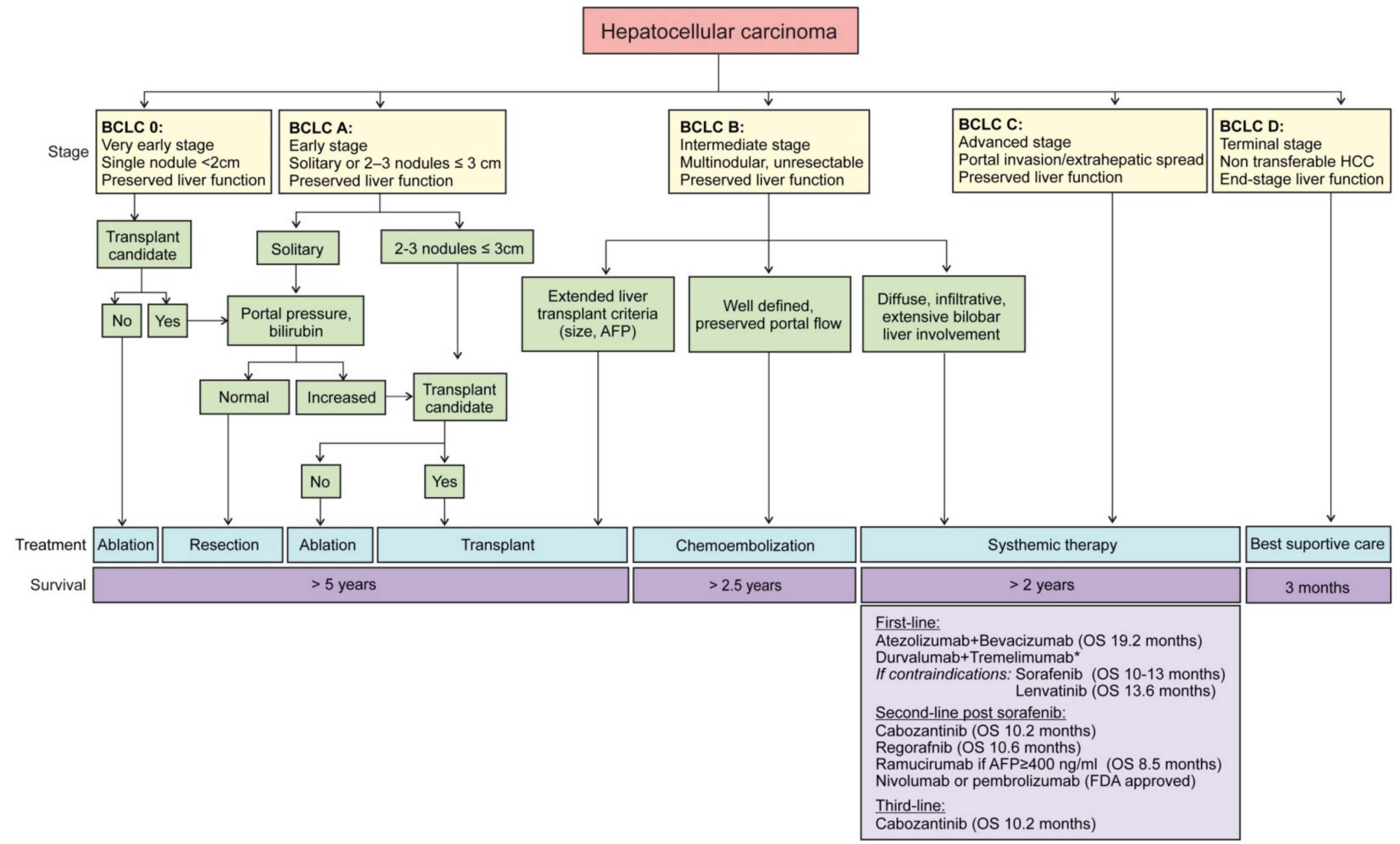

Figure 1. Updated treatment strategy in HCC management. The Barcelona Clinic Liver Cancer (BCLC) staging recommends HCC treatment in accordance with five defined stages. Local curative treatments including resection, ablation, or transplantation are endorsed for asymptomatic patients with preserved liver function and low tumor burden. Systemic therapies should be applied to patients in advanced stage or even in intermediate stage, when transplantation is not an option and chemoembolization not recommendable due to the presence of portal hypertension or the number/location of nodules. Current systemic therapies are presented. * Not yet FDA-approved, positive Phase III trial report.

\section{Tumor Microenvironment in HCC}

The interaction of the microenvironment with the tumor plays a relevant role in HCC pathogenesis (Figure 2). The tumor microenvironment is directly implicated in the modulation of liver fibrosis, the process of hepatocarcinogenesis, the epithelial-mesenchymal transition (EMT), invasion, and metastasis [53,54].

\subsection{Hepatic Stellate Cells}

Hepatic stellate cells (HSCs) are major components of liver connective tissue. They are localized in the basolateral surface of hepatocytes and the anti-luminal side of sinusoidal cells [55]. HSCs are in charge of vitamin A storage, synthesis of matrix metalloproteinases (MMPs) and extracellular matrix components (ECM, collagen), release of cytokines (IL-6 and IL-1 $\beta$ ), defensin-1, chemokines (CCL5, CCL2), and growth factors (TGF- $\alpha / \beta$, EGF, PDGF, bFGF) $[55,56]$. Normally, HSCs are in a quiescent state. Upon liver injury, they become activated, their cytoskeleton becomes remodeled through an increased expression of alpha-smooth muscle actin ( $\alpha$-SMA), and there is also a rise in cytokines, ECM components, and growth factors production [55]. In the activated state, HSCs transdifferentiate into myofibroblast-like cells. This phenotype makes them more contractile, so they can infiltrate the HCC stroma and localize around fibrous septa, sinusoids, and capsules [57,58]. 
Conditioned media from tumoral hepatocytes has been found to increase the proliferation of rat HSCs and induce the expression of HSCs' activation markers [59,60]. Similarly, another study demonstrated that collected media from HSCs potentiated the tumorigenic capacity of HCC cancer cell lines [61]. The co-culture of hepatoma cells and activated HSCs also revealed the activation of genes related to inflammation, chemotaxis, angiogenesis, and metalloproteinase from microarray analysis data [62,63]. Regarding in vivo studies, the co-implantation of HCC and HSCs cells in nude mice increased tumor growth via NF- $\mathrm{kB}$ and extracellular signal regulated kinase (ERK) pathways activation [61,64]. In this sense, previous work has showed that angiogenin was responsible for the crosstalk between HCC and HSCs cells both in vitro and in mice models [65].

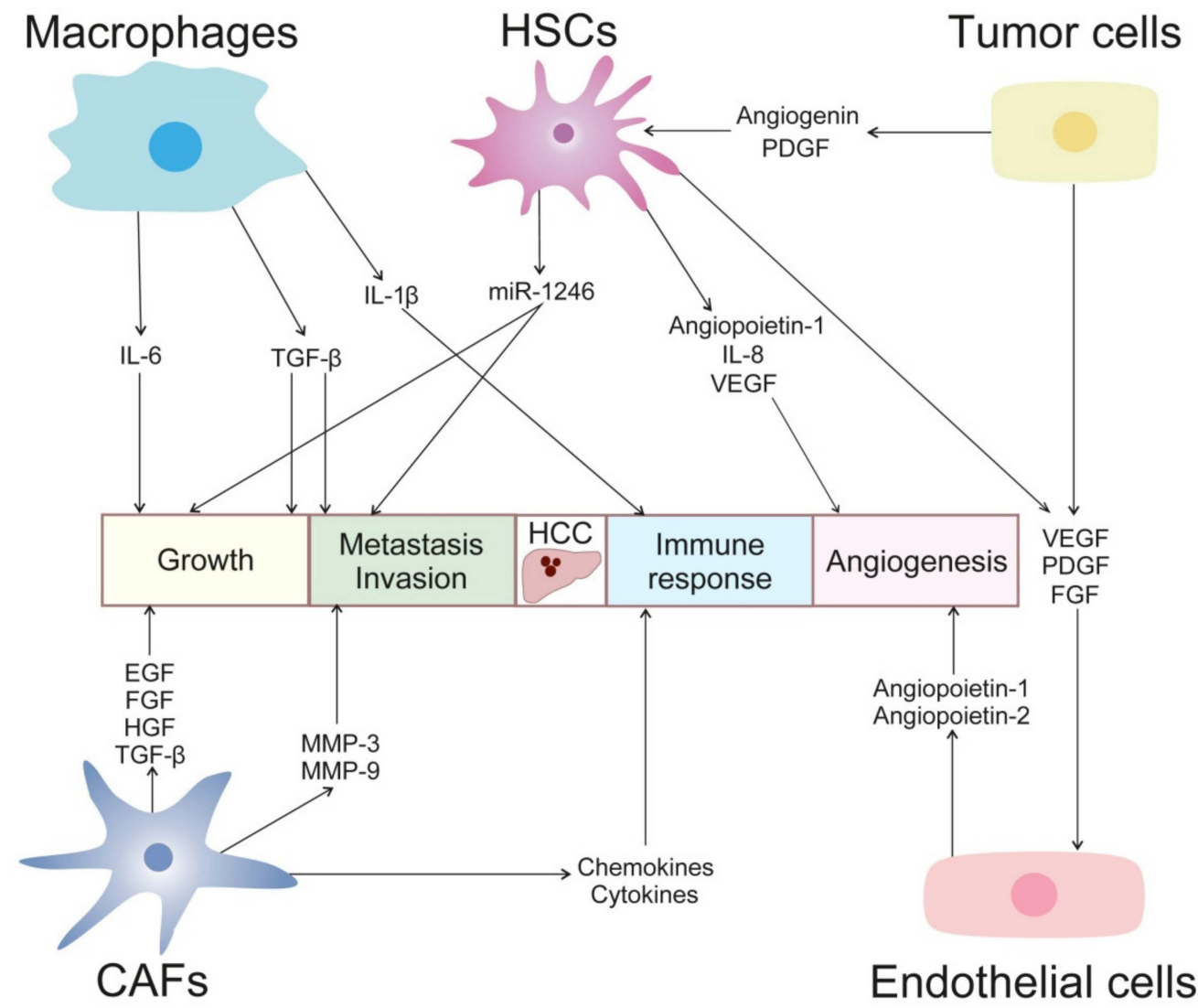

Figure 2. Cellular cross-talk in HCC development. Tumor microenvironment plays a critical role in HCC progression. Growth factors, cytokines, chemokines, metalloproteinases, miRNAs, and angiogenic factors mediate crosstalk between tumor, endothelial and stellate cells, fibroblast, macrophages, and other immune cells. These interactions promote tumor growth, neovascularization, invasion, and immunosuppression.

HSCs are also involved in the promotion of angiogenesis in HCC. Diverse mechanisms are responsible for this, among them the secretion of angiopoietin-1 [66] or IL-8 [67]. Moreover, PDGF secreted by tumor and endothelial cells has been described as attracting HSCs, while at the same time, HSCs secrete VEGF, thus promoting angiogenesis [68].

Several studies have pointed out that the secretion of IL-6 by HSCs may promote HCC progression [69,70]. In an HCC murine model with obesity, insulin resistance, and dyslipidemia, fatty acid binding protein 4 (FABP4) was enriched in intra-tumoral HSCs, contributing to hepatocarcinogenesis [71]. The co-culture of HSCs with HCC cells demonstrated that the overexpression of miR-1246 secreted by HSCs or the silencing of its target ROR $\alpha$ increased proliferation, invasion, and metastasis of HCC cells, with the involvement of the Wnt/ $\beta$-catenin pathway [72]. 
HSC s have also been described as promoting tumor chemoresistance. The laminin$332 / \alpha 3$ integrin axis and the ubiquitination of focal adhesion kinase (FAK) by HSCs were demonstrated to be involved in sorafenib chemoresistance [73]. In addition, FGF9, expressed only by HSCs, promoted the tumorigenic capacity of HCC cells and the resistance to sorafenib, and FGF9 overexpression was associated with poor prognosis in patients with HCC [74].

While most studies favor a role for HSCs in promoting HCC, HSCs have also been found to delay HCC progression. In particular, endosialin secreted by HSCs was reported to negatively regulate HCC proliferation in inducible mouse models of HCC [75].

\subsection{Cancer-Associated Fibroblasts}

Fibroblasts are present in the fibrillar matrix of connective tissue. They are responsible for wound healing, formation of extracellular matrix (ECM), tissue maturation, and the inflammatory response [76]. Cancer-associated fibroblasts (CAFs) are a sub-group of fibroblasts that are activated and implicated in cancer progression. Although CAFs arise from normal fibroblasts, CAFs can also derive from epithelial cells, endothelial cells, smooth muscle cells, bone marrow-derived progenitor cells, and pre-adipocytes [77]. Additionally, HCC tumors frequently develop in a cirrhotic liver in which there is a great amount of activated fibroblasts [78]. Therefore, CAFs may contribute to HCC tumor progression by producing growth factors (EGF, FGF, HGF, and TGF- $\beta$ ), chemokines (SDF-1), cytokines (IL-6), and metalloproteinases (MMP-3 and MMP-9) [79-81]. Moreover, the exosomal miR-1228-3p released by CAFs and directed to HCC cells was described as involved in chemoresistance [82]. In this regard, there is a growing amount of evidence showing that the crosstalk between CAFs and HCC tumors could be mediated by miRNAs contained in exosomes. For example, low miR-150-3p levels secreted by CAFs have been discovered to be involved in HCC migration and invasiveness as well as poor clinical outcome [83]. Interestingly, the upregulation of mirR-335-5p by CAFs inhibited HCC tumor cells proliferation in vitro and in vivo [84]. Moreover, HCC tumor cells were found to induce the conversion of HSCs into CAFs through the secretion of miR-21, which promoted cancer progression via the secretion of the angiogenic factors VEGF, MMP2, MMP9, bFGF and TGF- $\beta$ [85].

\subsection{Tumor-Associated Macrophages}

Macrophages around the tumor site are called tumor-associated macrophages (TAMs). Macrophages can display the M1 (classic) or M2 (alternative) phenotype depending on their tumor-suppressing or tumor-promoting role [86]. M1 macrophages produce Th1-cytokines, such as IFN- $\gamma$, and are activated by LPS and other microbial antigens. They exhibit high antigen-presenting capacity and increased cytotoxic activity, thereby producing reactive oxygen species (ROS) [87]. On the contrary, M2 macrophages are polarized by Th2-type cytokines IL-4, IL-13, glucocorticoids, and TGF- $\beta$. Their antigen-presenting capacity is low. M2 macrophages decrease inflammation, suppress the adaptive immune system, and promote tumor progression, angiogenesis, and tissue repair [88].

In HCC, M2 macrophages have been found to promote tumor progression and metastasis with the involvement of glypican-3, a member of the glypican family of heparin-sulfate proteoglycans reported to be highly expressed in the majority (>70\%) of HCCs [89]. In addition, TGF- $\beta 1$ secretion by TAMs promoted cancer progression and EMT in HCC $[90,91]$, and moreover, the TAM-production of IL-6, via STAT3, also promoted stemness in HCC [92]. Moreover, in a murine model of HCC, intra-tumoral macrophages expressing MMP-9 were involved in ECM remodeling, thus favoring tumor progression [93], while, in another study, the presence of TAMs correlated with tumor vascularity, pointing towards the ability of TAMs to promote angiogenesis [94].

It has been shown, in Hepa1-6 HCC tumors, that, in the early phase of tumor development, infiltrated macrophages displayed a tumor-suppressing phenotype, while, at advanced stages, the TAM population increases and is associated with tumor progression [95]. Thus, it is becoming apparent that macrophage polarization plays a crucial role in 
the initiation of liver diseases, and its role in HCC needs to be further clarified, particularly since it may affect immunotherapy efficacy [96]. At the same time, tumor cells have been found to release Wnt ligands that promoted M2 polarization of macrophages and, in turn, promoted tumor growth, invasion, and immunosuppression in HCC [97]. In this regard, treatment of HCC with sorafenib has been shown to induce the repolarization of alternative macrophages to M1 phenotype through IGF-1 signaling [98].

Additionally, in HCC human samples, TAM infiltration was linked with PD-L1 overexpression [99]. Although M1 macrophages have been considered to exert an anti-tumor role, M1 macrophages my promote PD-L1 expression in HCC tumor cells, highlighting the potential role of M1 macrophages in tumor promotion through IL-1 $\beta$ pathway [100]. In fact, Kupffer cells, resident macrophages in the liver, have been reported to mediate tumor growth in HCC by producing PD-L1 that interacts with PD-1 receptor in CD8 ${ }^{+} \mathrm{T}$ cells, impairing $\mathrm{CD}^{+} \mathrm{T}$ cell response [101]. In addition, Kupffer cells produce osteopontin, which is involved in inflammation, tumor progression, and metastasis [102].

\subsection{Endothelial Cells}

Endothelial cells (ECs) are present in the interior face of blood vessels. Other cells, such as HSCs, participate in controlling the size and elasticity of liver vessels [103]. The interactions of ECs with the ECM and basement membrane proteins play a role in proliferation, stability, and neoangiogenesis. When the basement membrane degrades, ECs become exposed to collagen, which triggers the formation of new blood vessels [104]. Neovascularization favors tumor proliferation, invasion, and metastasis, since the new blood supply provides oxygen and nutrients to the tumor [105]. Tumor blood vessels have structural abnormality and increased permeability. ECs carry angiogenic receptors, for instance VEGFR, EGFR, PDGFR, and CXCR [106]. Additionally, hypoxia is a known driver of tumor angiogenesis. Many studies conducted in HCC preclinical models have shown that hypoxia-inducible factor (HIF) proteins led to the activation of VEGF, which promotes angiogenesis [107-109]. VEGF and VEGFRs are crucial for HCC development [110,111]. The binding of VEGF ligands to their receptors elicits downstream phosphorylation that results in EC proliferation and the formation of new branches of blood vessels [112]. High VEGF levels in serum have been found to be associated with bad prognosis in HCC patients who underwent surgical resection [113], since sVEGF concentration has been showed to correlate with angiogenesis, invasion, and metastasis of HCC [114]. The interaction of platelet-derived growth factors (PDGF) with PDGF receptors (PDGFR) triggers the activation of the same signaling pathways as the binding of VEGF and VEGFRs not only in ECs but also in fibroblasts, smooth muscle cells, and HSCs [115]. In this sense, PDGFR $\alpha$ expression was associated with microvascular invasion [116].

Additionally, fibroblast growth factor (FGF) and fibroblast growth factor receptors (FGFR) also regulate cell growth and angiogenesis [117]. Basic fibroblast growth factor (bFGF) fostered VEGF expression and its synergistic effect contributed to HCC development and neovascularization [118]. Of interest, angiopoietin-1 (Ang-1) and 2 (Ang-2) bind to their receptor, Tie2, to stimulate angiogenesis [119]. Ang-1 and Ang-2 expression was detected in hepatoma, HSCs, ECs, and smooth muscle cells, while Tie2 receptor was only identified in ECs, HSCs, smooth muscle cells, and monocytes [120,121]. Ang-2 serum levels were high in patients with cirrhosis and HCC [122], being a prognosis marker [123]. Ang-2 exhibited a synergistic effect with VEGF in the development of angiogenesis in HCC in mice through the activation of MMP-2 and MMP-9 [124]. Ang-2 was included in a five-gene signature that effectively predicted HCC rapid growth [125]. As other pro-angiogenic factors, Ang-2 also played a role in the promotion of HCC invasion and metastasis [126].

\subsection{Tumor-Associated Cells of the Innate Immune System}

Innate immune mechanisms may support or neutralize tumor-related immune activation, being recognized drivers of disease progression in the liver, particularly during conditions such as fibrosis or cirrhosis prior to HCC. Exhaustive research has been devel- 
oped to delineate the immunological steps involved in the initiation and evolution of liver cancer. During HCC progression, several studies analyzing the response to immunotherapy have leaded to conflicting results, probably due to the complex and only partially known interactions between specific immune cells, tumor cells, and the different cells that configure the tumor microenvironment. For reviews on the subject, see $[127,128]$.

Forgotten during years, tumor-infiltrating immune cells in the HCC have been recently evaluated and characterized [128]. For many solid tumors, including HCC, different relationships between immune cell populations and therapy efficacy and prognosis have been suggested. While the complete impact of the tumor immune environment is still to be determined, myeloid cells including TAMs and myeloid-derived suppressor cells (MDSCs) are abundantly present in the HCC microenvironment being frequently associated with poor prognosis. In general, myeloid cells in HCC play a very active role in promoting tumor initiation, development, angiogenesis, metastasis, and even therapeutic resistance [129]. In contrast, increasing numbers of infiltrating T-effector cells are habitually linked with a good prognosis [130]. Generally, a pro-inflammatory HCC ambient with infiltrating natural killer (NK) cells, and CD8-expressing T cells are considered to be positive and associated with good clinical outcomes in numerous tumor types [131]. NK cells play a central role in hepatic immunity, accounting for $25-50 \%$ of the total number of liver lymphocytes. Both circulating and tumor infiltrating NK cells are positively correlated with patient survival benefit in HCC [132], contrary to other immune cells, such as MDSCs and regulatory T cells, which seem to disrupt the immune control of the HCC [130].

\section{Systemic Therapies for HCC}

Clinical treatment of HCC includes surgical therapies, resection or tumor ablation, transplantation, transarterial chemoembolization (TACE), therapies that have been extensively revised [13,42,43].

HCC patients with a single tumor and preserved liver function are candidates for resection. Liver transplantation benefits patients who are not good candidates for surgical resection and who present with a solitary tumor $\leq 5 \mathrm{~cm}$ or up to three nodules $\leq 3 \mathrm{~cm}$. Image-guided ablation is the most frequently used therapeutic strategy, but its efficacy is limited by the size of the tumor and its localization. TACE has survival benefit in asymptomatic patients with multifocal disease without vascular invasion or extrahepatic spread [42]. Finally, systemic therapies are only recommended in advanced HCC and with well-preserved liver function [42]. No systemic drugs were available for patients with advanced stage HCC until 2007, when sorafenib was approved [43]. Sorafenib increased the available treatment options for patients with extrahepatic spread and vascular invasion and improved survival in patients with advanced HCC.

Nonetheless, various limitations such as low response rates, resistance to sorafenib, or adverse effects (e.g., hand-foot skin reaction) prompted concerted efforts aimed at developing new molecular targeted agents to provide more treatment options and secondline agents for patients with disease progression or intolerance to sorafenib.

Of importance, during the past five years, many trials have been made in the search for novel and more effective systemic treatments for advanced HCC, not only as first-line but also as second-line, as recently reviewed in an EASL position paper aimed at helping clinicians provide the best possible care for patients today [133]. Therefore, as of today, drugs licensed in some countries include four oral multi-tyrosine kinase inhibitors (MKIs) (sorafenib, lenvatinib, regorafenib, and cabozantinib), one anti-angiogenic antibody (ramucirumab), and four immune checkpoint inhibitors, alone or in combination (atezolizumab in combination with bevacizumab, ipilimumab in combination with nivolumab, nivolumab and pembrolizumab in monotherapy) (Figure 3).

According to this updated guidelines, in the next paragraph we will introduce the systemic treatments approved in recommended order of use. 


\subsection{First-Line Therapies}

\subsubsection{Atezolizumab-Bevacizumab (Atezo-Bev)}

To date, atezolizumab and bevacizumab combination is the first treatment superior to sorafenib demonstrating prolonged overall survival $(67.2 \%$ vs. $54.6 \%$; hazard ratio [HR] 0.58) and progression-free survival (6.8 months vs. 4.3 months; HR 0.59) [134]. The success of IMbrave 150 clinical trial has changed the paradigm of HCC treatment, and atezo-bev has become the recommended systemic therapy if no contraindications are present [133].

Atezolizumab (Tecentriq) is a humanized IgG1 monoclonal antibody that targets PD-L1 to prevent its binding with PD-1 and B7-1 receptors, thus reversing T-cell suppression [135]. Bevacizumab (Avastin) is a monoclonal antibody that targets vascular endothelial growth factor (VEGF), inhibiting angiogenesis and tumor growth [110]. Anti-VEGF therapy also enhances anti-PD-1/PD-L1 activity by reducing VEGF-mediated immunosuppression and promoting T-cell infiltration in tumors [136]. Of note, other immune checkpoint inhibitors [137,138], as well as atezolizumab [139], in monotherapy, did not reach better outcome in HCC patients, highlighting the synergistic efficacy of immunotherapy and anti-angiogenic combination.

Regarding adverse effects, hypertension and increased AST or ALT are grade 3 or 4 adverse events frequently observed after atezo-bev treatment. Moreover, bleeding, a lifethreatening risk for cirrhotic patients, is a common reaction to bevacizumab. In this sense, risk of bleeding, comorbidities such as arterial hypertension and cardiovascular disease, and prior autoimmune conditions may become limiting parameters for the indication of atezo-bev. If the patient has contraindications to atezo-bev, alternative therapies should be considered, such as sorafenib or lenvatinib.

Another immune-based therapy that will likely be included in the first line soon is the tremelimumab/durvalumab combination. Although the peer review data have not yet been published, a significant survival benefit over sorafenib has been announced in the HIMALAYA phase III trial. Once the study data are fully available, changes in clinical decision-making are expected in such a setting, although these are now difficult to foresee.

\subsubsection{Sorafenib}

Sorafenib (Nexavar) is a small molecule that inhibits the phosphorylation of up to 40 tyrosine kinases, including VEGFR1, 2 and 3, PDGFR $\beta, \mathrm{KIT}$, and RET. This tyrosine kinase inhibitor (TKI) also suppresses Raf kinase isoforms, such as wild-type Raf1, B-Raf, and mutant b-raf V600E. Sorafenib displayed anti-proliferative, anti-angiogenic, and proapoptotic properties in HCC cell lines [140], anti-tumor activity in tumor xenograft nude mice [141], and anti-metastatic effect in preventing postsurgical recurrence in an orthotopic mouse model [142]. The efficacy of sorafenib possibly lays in its capacity to target both tumor cells and their microenvironment [6]. As an example, it has been described that sorafenib also had an impact on HSCs proliferation by the suppression of $\alpha$-SMA and PDGF-related pathways, which decreased HCC cell viability [143]. However, a high dose of sorafenib has been described as promoting immunosuppression through the induction of PD-1 expression in infiltrating immune cells in a murine HCC model [144]; whether this could affect patients, particularly those under immunotherapy, is an aspect that deserves to be studied. 


\section{PROLIFERATION/EMT}
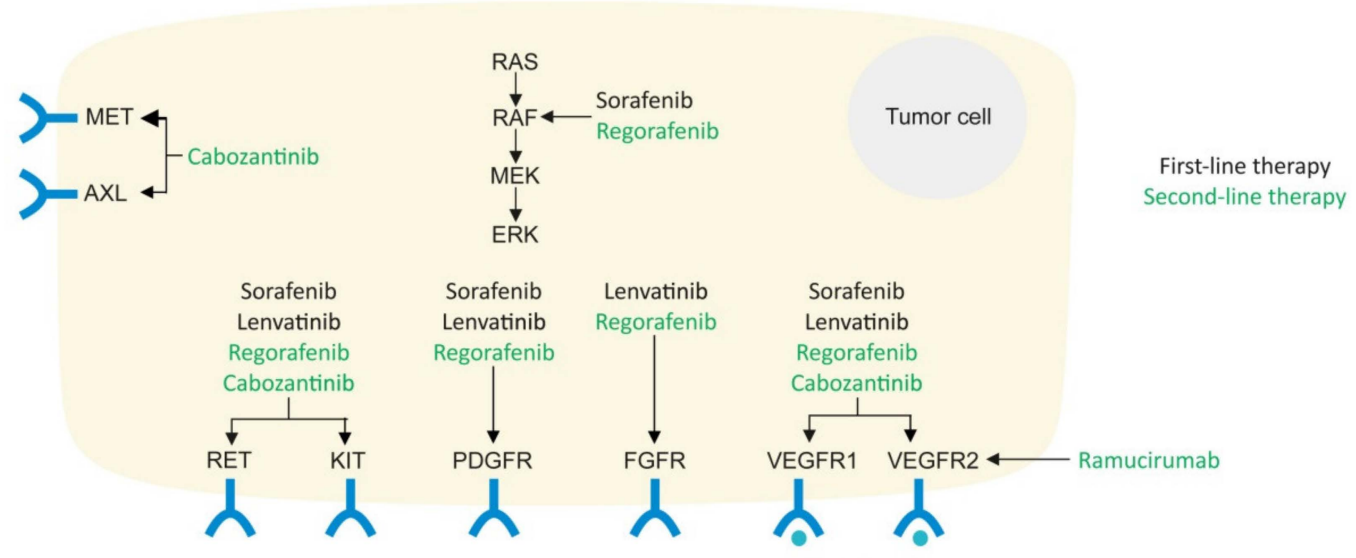

IMMUNOSUPRESSION

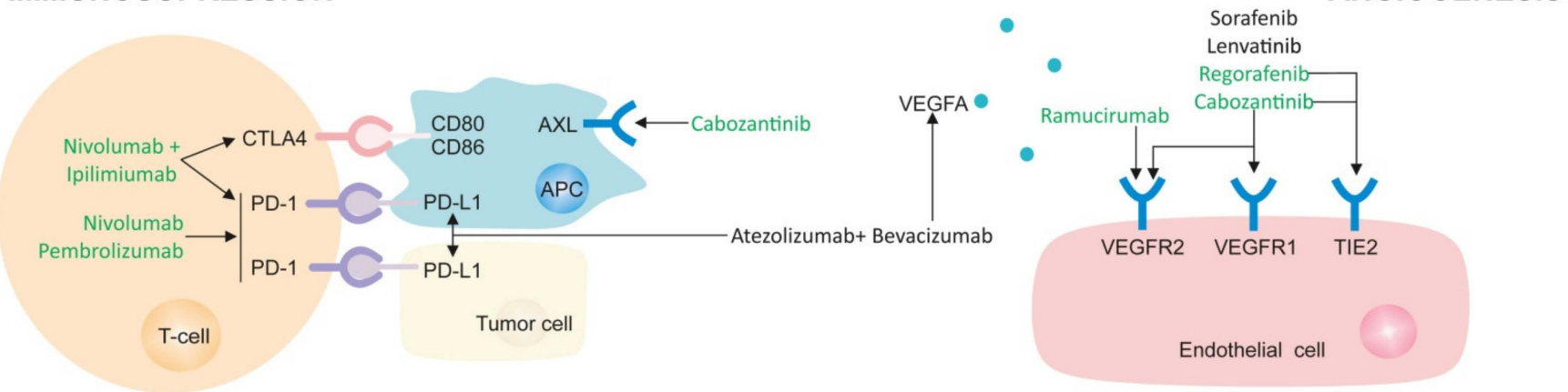

Figure 3. The mechanisms of action of currently approved molecular therapies. Main targets are indicated for each drug and separated depending on the activity against proliferation/EMT with multikinase inhibitors, decreasing angiogenesis in tumor microenvironment, or blocking tumor immunosuppression with checkpoint inhibitors.

Sorafenib was the first compound that demonstrated survival benefit in HCC in a phase 3, double-blind trial versus placebo (SHARP trial). The median overall survival for patients in the sorafenib arm was 10.7 months compared to 7.9 months in the control group (HR $0.69,95 \%$ confidence interval $0.55-0.87, p<0.001$ ) [145]. In a parallel trial conducted in the Asian-Pacific population, sorafenib showed a similar survival benefit [146]. The most common adverse effects are diarrhea (8-9\% patients) and a hand-foot skin reaction (8-16\% patients) [145]. Sorafenib is recommended as the standard systemic therapy for HCC in the first line setting in patients with well-preserved liver function (Child-Pugh A or early B class), with advanced tumors, BCLC-C, or tumors that progressed after loco-regional therapies [43]. The appearance of dermatologic reactions has been linked to better survival following sorafenib administration [147].

Among the molecular mechanisms responsible for sorafenib effectivity in HCC cells is the activation of programmed cell death, apoptosis, provoked by the downregulation of myeloid cell leukemia sequence 1 (MCL-1) expression, an anti-apoptotic member of the BCL-2 family [148]. Recent data have shown that the mitochondrial link with sorafenib activity is more profound. Sorafenib induces mitochondrial reactive oxygen species (ROS), depletes mitochondrial membrane potential, and induces changes in the BCL-2/MCL-1 ratio $[149,150]$. In fact, continuous sorafenib exposure altered the levels of anti-apoptotic BCL-2 proteins allowing HCC cell death escape. In contrast, surviving cells are sensitized against BH3-mimetics, inhibitors of specific BCL-2 proteins such as navitoclax [150]. Sorafenib has also been described as involved in the autophagy pathway. The administration of autophagy inhibitors, such as chloroquine or pemetrexed, improved sorafenib efficacy in tumor cells and nude mice hepatoma tumors [151]. Additionally, MCL-1 downregulation 
was found to disrupt the MCL-1:Beclin 1 complex and induce autophagic cell death in HCC cell lines [152]. In fact, as a consequence of the mitochondrial damage induced by sorafenib, mitophagy is also activated by a triggering mechanism that involves mitochondrial ROS production [153], allowing sorafenib activity to be modulated by antioxidant administration [154]. Acquired drug resistance, which reduces sorafenib effectiveness in patients, may depend on these or other mechanisms. HCC is highly heterogeneous, within the tumor and among individuals, and this influences disease progression, classification, prognosis, and, naturally, cellular susceptibility to drug resistance. In this sense, long-term exposure to sorafenib of hepatoma cells provoked the acquisition of chemoresistance, as well as EMT features [155,156]. Hypoxia has been described to be involved in sorafenib resistance due to HIF- $1 \alpha$ and NF- $\mathrm{BB}$ activation [157]. Moreover, M2 macrophages have been found to participate in sorafenib resistance by the release of HGF [158].

\subsubsection{Lenvatinib}

Lenvatinib (Lenvima) is an inhibitor of VEGFRs, RET, KIT, PDGFR $\alpha$, and FGFR1FGFR4 [159]. It also displayed anti-angiogenic properties and anti-FGFRs activity in hepatoma cells and xenografts $[160,161]$. Lenvatinib has been described to exert an immunomodulatory effect through the increase of $\mathrm{CD}^{+} \mathrm{T}$ cell population while diminishing macrophages and monocytes populations in HCC cells [162].

In a phase 3 clinical trial, lenvatinib showed to be non-inferior to sorafenib in terms of overall survival. Hypertension, diarrhea, or a decrease in appetite or weight were among the most common adverse events [163]. In a small group of patients, the levels of AFP were found to decrease in the next two weeks following treatment, suggesting that AFP levels could be predictive of patients' response [164]. Furthermore, circulating FGF-19 and Ang-2 have been proposed as predictors of clinical response to lenvatinib in HCC patients [165,166], as well as an early tumor shrinkage [167]. However, like sorafenib, HCC has been described as displaying resistance against lenvatinib. The HGF/c-MET signaling activation was identified as one mechanism of lenvatinib tolerance [168].

\subsection{Second-Line Therapies}

\subsubsection{Regorafenib}

Regorafenib (Stivarga) is a multikinase inhibitor (MKI) against VEGFR-2, VEGFR-3, KIT, RET, wild-type, and mutant (V600E) B-Raf, PDGFR, FGFR1, angiopoietin 1 receptor (TIE2), RET, and p-38-alpha. Its inhibitory profile is slightly different from sorafenib, since regorafenib has stronger potency targeting VEGFR and TIE2, KIT, and RET [169]. Like sorafenib, regorafenib inhibits angiogenesis, oncogenesis, and tumor microenvironment. Regorafenib was shown to block cell growth and invasion in hepatoma cell lines [170]. This MKI also targeted MAPK pathway, induced caspase cleavage and activated the autophagic pathway [171,172], and mitophagy as a consequence of its mitochondrial activity [154]. In fact, regorafenib alteration of mitochondrial proteins such as BCL-xL is related to regorafenib resistance, pointing to BH3 mimetics for combined therapies [173]. Moreover, both intrinsic and extrinsic apoptotic pathways were activated by regorafenib [174]. The treatment with regorafenib provoked a decrease in the expression of metastasis-related proteins in HCC cells [175]. Regorafenib was demonstrated to block EMT activation and overcome the acquired resistance to sorafenib [176].

The RESORCE trial was the first phase 3 clinical trial that showed that patients who progressed on sorafenib benefited from oral regorafenib administration versus placebo in a second line setting [177]. Median survival was 10.6 months for the regorafenib arm, while 7.8 months for the control group (HR 0.63; 95\% 0.50-0.79; $p<0.0001$ ). Manageable adverse events consisted of a hand-foot skin reaction, hypertension, and fatigue. Additional analyses of the RESORCE trial have suggested that the administration of regorafenib following sorafenib may extend survival [178]. 


\subsubsection{Cabozantinib}

Cabozantinib (Cometriq, Cabometyx) is a small molecule with tyrosine kinase inhibitory prolife against VEGFR-2, RET, KIT, FLT-3, TIE2, and AXL. Cabozantinib differs from sorafenib and regorafenib in that it is capable to also block c-Met [179]. Cabozantinib has demonstrated anti-tumor activity in HCC cells by inhibiting tumor growth, angiogenesis, invasion, and migration. It also reduced the number of HCC metastatic nodules in the lungs and liver in mice [180]. In a phase two clinical trial, cabozantinib demonstrated effectivity in HCC patients [181]. Those promising results led to the conduction of a phase 3 clinical trial in patients who progressed after sorafenib treatment. Cabozantinib increased overall survival (10.2 months) compared to placebo (8.0 months, HR $0.76 ; 95 \% \mathrm{CI}, 0.63-0.92 ; p=0.005)$. The most frequent side effects were palmar-plantar erythrodysesthesia, hypertension, increase AST, fatigue, and diarrhea [182].

\subsubsection{Nivolumab}

Nivolumab (Opdivo) is a human monoclonal antibody that targets programmed cell death protein 1 (PD-1). It is an immune checkpoint inhibitor, since nivolumab impedes the signaling that blocks $T$ cell anti-tumor activity [183]. A phase $1 / 2$ dose escalation study performed with advanced HCC with or without previous sorafenib treatment showed the potential of nivolumab for the treatment of HCC (CheckMate 040 trial) [184]. A further analysis of the CheckMate 040 trial highlighted that some inflammatory biomarkers trended with improved survival and an anti-tumor immune response [185]. Nevertheless, a subset of patients with hyperprogressive disease (HPD) was identified after nivolumab treatment in HCC patients [186]. Furthermore, administration of nivolumab plus ipilimumab, which targets CTLA-4, a inhibitory T-cell receptor, also showed to be a promising therapeutic strategy in HCC patients who progressed on sorafenib [187].

\subsubsection{Pembrolizumab}

The humanized monoclonal antibody pembrolizumab (Keytruda) blocks PD-1 as well. In a non-randomized phase 2 clinical trial, pembrolizumab was effective in patients who were treated previously with sorafenib (KEYNOTE-224) [188]. These results led to testing pembrolizumab compared to placebo in a phase 3 randomized clinical trial. Although median overall survival was longer for the pembrolizumab arm, 13.9 months $(95 \% \mathrm{CI}$, 11.6 to 16.0 months) and 10.6 months (95\% CI, 8.3 to 13.5 months) for placebo, the results were not statistically significant [137].

\subsubsection{Ramucirumab}

Regarding antiangiogenic therapies, ramucirumab (Cyramza), a monoclonal antibody against VEGFR2 [189-191], failed to improve survival in the REACH trial in patients treated previously with sorafenib. However, the authors identified AFP serum levels as a prognostic marker showing that patients with high levels of AFP $(\geq 400 \mathrm{ng} / \mathrm{mL})$ benefit from ramucirumab treatment. These observations were validated in REACH-2, a doubleblind phase III trial, wherein only patients treated with sorafenib with high AFP levels were included. Ramucirumab improved overall survival (8.5 versus 7.3 months HR $0.710,95 \%$ CI $0.531-0.949 ; p=0.0199$ ) and has become the first HCC therapy with biomarker-guided patient selection. Hypertension, liver failure, and hyponatremia were the most common grade $3-4$ adverse events.

\subsubsection{Combination Therapies}

Regarding ongoing clinical studies, several combinations of treatment regimens are being tested in patients with HCC in both the first line and second line: the RENOBATE study (combination of regorafenib and nivolumab administered as first-line therapy in unresectable HCC), the REGOMUNE trial (avelumab, which targets PD-L1, will be studied together with regorafenib), the GOING trial (second-line treatment with regorafenib, followed by nivolumab treatment in patients who have progressed on sorafenib admin- 
istration), the ACTION trial (will evaluate the effectivity of cabozantinib in patients who are sorafenib-intolerant or who do not meet the RESORCE criteria), and the COSMIC-312 clinical trial (administration of cabozantinib in combination with the immune checkpoint inhibitor atezolizumab), among some others.

\section{Conclusions}

After years without major therapeutic improvements and with increasing incidence, finally advances are arriving for HCC treatment. Sorafenib is no longer the only systemic therapy for patients, and novel combinations are already working in clinical trials. Accumulating data demonstrate that etiology and the HCC microenvironment have a major influence on tumor growth and immune control. The improved knowledge of the specific molecular mechanisms involved is expected to provide evidence-based information critical for clinical management. Based on that, novel recommendations for treatment are already being suggested that should help physicians [192]. A diligent effort from translational researchers is required to provide tools to facilitate decision-making, and careful analysis of the novel therapeutic strategies will be necessary to ensure rapid benefit for HCC patients. Important steps to revert the dismal prognosis associated with HCC have been made, and now is time to decide the next ones and to guarantee their correct implementation.

Author Contributions: Conceptualization, M.M. and A.M.; writing original draft preparation, B.C. and A.T.; writing, review and editing, P.R., T.H.-A., C.C., P.G.d.F., A.C., M.M. and A.M.; funding acquisition, P.G.d.F., A.C., M.M. and A.M. All authors have read and agreed to the published version of the manuscript.

Funding: This research was funded by Instituto de Salud Carlos III, grant number PI19/01410 to M.M.; CIBEREHD and CIBERNED; Ministerio de Ciencia e Innovación, grant numbers RTI2018095672-B-I00 to A.M. and P.G.F. and RTI2018-095572-B-100 to A.C.; and co-funded by FEDER (Fondo Europeo de Desarrollo Regional, Unión Europea); Ayuda Extraordinaria CSIC 2021AEP095 to A.M. and P.G.F., AGAUR, grant number 2017_SGR_177 to A.M.; Fundació la Marató de TV3 to A.M.; and CERCA Programme/Generalitat de Catalunya.

Conflicts of Interest: The authors declare no conflict of interest. The funders had no role in the design of the study; in the collection, analyses, or interpretation of data; in the writing of the manuscript, or in the decision to publish the results.

\section{References}

1. Ferlay, J.; Ervik, M.; Lam, F.; Colombet, M.; Mery, L.; Piñeros, M.; Znaor, A.; Soerjomataram, I.; Bray, F. Global Cancer Observatory: Cancer Today; International Agency for Research on Cancer: Lyon, France, 2018; pp. 1-6.

2. Sung, H.; Ferlay, J.; Siegel, R.L.; Laversanne, M.; Soerjomataram, I.; Jemal, A.; Bray, F. Global Cancer Statistics 2020: GLOBOCAN Estimates of Incidence and Mortality Worldwide for 36 Cancers in 185 Countries. CA Cancer J. Clin. 2021, 71, 209-249. [CrossRef] [PubMed]

3. Petrick, J.L.; Florio, A.A.; Znaor, A.; Ruggieri, D.; Laversanne, M.; Alvarez, C.S.; Ferlay, J.; Valery, P.C.; Bray, F.; McGlynn, K.A. International trends in hepatocellular carcinoma incidence, 1978-2012. Int. J. Cancer 2020, 147, 317-330. [CrossRef] [PubMed]

4. McGlynn, K.A.; Petrick, J.L.; El-Serag, H.B. Epidemiology of Hepatocellular Carcinoma. Hepatology 2021, 73 (Suppl. 1), 4-13. [CrossRef] [PubMed]

5. Mittal, S.; El-Serag, H.B. Epidemiology of hepatocellular carcinoma: Consider the population. J. Clin. Gastroenterol. 2013, 47, S2-S6. [CrossRef] [PubMed]

6. Llovet, J.M.; Zucman-Rossi, J.; Pikarsky, E.; Sangro, B.; Schwartz, M.; Sherman, M.; Gores, G. Hepatocellular carcinoma. Nat. Rev. Dis. Prim. 2016, 2, 16018. [CrossRef] [PubMed]

7. Singh, S.; Singh, P.P.; Singh, A.G.; Murad, M.H.; Sanchez, W. Statins are associated with a reduced risk of hepatocellular cancer: A systematic review and meta-analysis. Gastroenterology 2013, 144, 323-332. [CrossRef]

8. Bravi, F.; Bosetti, C.; Tavani, A.; Bagnardi, V.; Gallus, S.; Negri, E.; Franceschi, S.; La Vecchia, C. Coffee drinking and hepatocellular carcinoma risk: A meta-analysis. Hepatology 2007, 46, 430-435. [CrossRef]

9. Sia, D.; Villanueva, A.; Friedman, S.L.; Llovet, J.M. Liver Cancer Cell of Origin, Molecular Class, and Effects on Patient Prognosis. Gastroenterology 2017, 152, 745-761. [CrossRef]

10. Mu, X.; Español-Suñer, R.; Mederacke, I.; Affò, S.; Manco, R.; Sempoux, C.; Lemaigre, F.P.; Adili, A.; Yuan, D.; Weber, A.; et al. Hepatocellular carcinoma originates from hepatocytes and not from the progenitor/biliary compartment. J. Clin. Investig. 2015, 125, 3891. [CrossRef] 
11. Llovet, J.M.; Kelley, R.K.; Villanueva, A.; Singal, A.G.; Pikarsky, E.; Roayaie, S.; Lencioni, R.; Koike, K.; Zucman-Rossi, J.; Finn, R.S. Hepatocellular carcinoma. Nat. Rev. Dis. Prim. 2021, 7, 6. [CrossRef]

12. Llovet, J.M.; Montal, R.; Sia, D.; Finn, R.S. Molecular therapies and precision medicine for hepatocellular carcinoma. Nat. Rev. Clin. Oncol. 2018, 15, 599-616. [CrossRef] [PubMed]

13. Villanueva, A. Hepatocellular carcinoma. N. Engl. J. Med. 2019, 380, 1450-1462. [CrossRef] [PubMed]

14. Nault, J.-C.; Couchy, G.; Balabaud, C.; Morcrette, G.; Caruso, S.; Blanc, J.-F.; Bacq, Y.; Calderaro, J.; Paradis, V.; Ramos, J.; et al. Molecular Classification of Hepatocellular Adenoma Associates With Risk Factors, Bleeding, and Malignant Transformation. Gastroenterology 2017, 152, 880-894.e6. [CrossRef] [PubMed]

15. Schulze, K.; Nault, J.-C.; Villanueva, A. Genetic profiling of hepatocellular carcinoma using next-generation sequencing. J. Hepatol. 2016, 65, 1031-1042. [CrossRef]

16. Schulze, K.; Imbeaud, S.; Letouzé, E.; Alexandrov, L.B.; Calderaro, J.; Rebouissou, S.; Couchy, G.; Meiller, C.; Shinde, J.; Soysouvanh, F.; et al. Exome sequencing of hepatocellular carcinomas identifies new mutational signatures and potential therapeutic targets. Nat. Genet. 2015, 47, 505-511. [CrossRef]

17. Audard, V.; Grimber, G.; Elie, C.; Radenen, B.; Audebourg, A.; Letourneur, F.; Soubrane, O.; Vacher-Lavenu, M.-C.; Perret, C.; Cavard, C.; et al. Cholestasis is a marker for hepatocellular carcinomas displaying beta-catenin mutations. J. Pathol. 2007, 212, 345-352. [CrossRef]

18. Hsu, I.C.; Metcalf, R.A.; Sun, T.; Welsh, J.A.; Wang, N.J.; Harris, C.C. Mutational hotspot in the p53 gene in human hepatocellular carcinomas. Nature 1991, 350, 427-428. [CrossRef]

19. Bressac, B.; Kew, M.; Wands, J.; Ozturk, M. Selective G to T mutations of p53 gene in hepatocellular carcinoma from southern Africa. Nature 1991, 350, 429-431. [CrossRef] [PubMed]

20. Guichard, C.; Amaddeo, G.; Imbeaud, S.; Ladeiro, Y.; Pelletier, L.; Maad, I.B.; Calderaro, J.; Bioulac-Sage, P.; Letexier, M.; Degos, F.; et al. Integrated analysis of somatic mutations and focal copy-number changes identifies key genes and pathways in hepatocellular carcinoma. Nat. Genet. 2012, 44, 694-698. [CrossRef]

21. Sporn, M.B.; Liby, K.T. NRF2 and cancer: The good, the bad and the importance of context. Nat. Rev. Cancer 2012, 12, 564-571. [CrossRef]

22. Sawey, E.T.; Chanrion, M.; Cai, C.; Wu, G.; Zhang, J.; Zender, L.; Zhao, A.; Busuttil, R.W.; Yee, H.; Stein, L.; et al. Identification of a therapeutic strategy targeting amplified FGF19 in liver cancer by Oncogenomic screening. Cancer Cell 2011, 19, 347-358. [CrossRef] [PubMed]

23. Horwitz, E.; Stein, I.; Andreozzi, M.; Nemeth, J.; Shoham, A.; Pappo, O.; Schweitzer, N.; Tornillo, L.; Kanarek, N.; Quagliata, L.; et al. Human and mouse VEGFA-amplified hepatocellular carcinomas are highly sensitive to sorafenib treatment. Cancer Discov. 2014, 4, 730-743. [CrossRef] [PubMed]

24. Zehir, A.; Benayed, R.; Shah, R.H.; Syed, A.; Middha, S.; Kim, H.R.; Srinivasan, P.; Gao, J.; Chakravarty, D.; Devlin, S.M.; et al Mutational landscape of metastatic cancer revealed from prospective clinical sequencing of 10,000 patients. Nat. Med. 2017, 23, 703-713. [CrossRef] [PubMed]

25. Toffanin, S.; Hoshida, Y.; Lachenmayer, A.; Villanueva, A.; Cabellos, L.; Minguez, B.; Savic, R.; Ward, S.C.; Thung, S.; Chiang, D.Y.; et al. MicroRNA-based classification of hepatocellular carcinoma and oncogenic role of miR-517a. Gastroenterology 2011, 140, 1618-1628.e16. [CrossRef]

26. Zucman-Rossi, J.; Villanueva, A.; Nault, J.-C.; Llovet, J.M. Genetic Landscape and Biomarkers of Hepatocellular Carcinoma. Gastroenterology 2015, 149, 1226-1239.e4. [CrossRef]

27. Hoshida, Y.; Toffanin, S.; Lachenmayer, A.; Villanueva, A.; Minguez, B.; Llovet, J.M. Molecular classification and novel targets in hepatocellular carcinoma: Recent advancements. Semin. Liver Dis. 2010, 30, 35-51. [CrossRef]

28. Llovet, J.M.; Villanueva, A.; Lachenmayer, A.; Finn, R.S. Advances in targeted therapies for hepatocellular carcinoma in the genomic era. Nat. Rev. Clin. Oncol. 2015, 12, 408-424. [CrossRef]

29. Boyault, S.; Rickman, D.S.; de Reyniès, A.; Balabaud, C.; Rebouissou, S.; Jeannot, E.; Hérault, A.; Saric, J.; Belghiti, J.; Franco, D.; et al. Transcriptome classification of HCC is related to gene alterations and to new therapeutic targets. Hepatology 2007, 45, 42-52. [CrossRef]

30. Villanueva, A.; Hoshida, Y.; Battiston, C.; Tovar, V.; Sia, D.; Alsinet, C.; Cornella, H.; Liberzon, A.; Kobayashi, M.; Kumada, H.; et al. Combining clinical, pathology, and gene expression data to predict recurrence of hepatocellular carcinoma. Gastroenterology 2011, 140, 1501-1512.e2. [CrossRef]

31. Lachenmayer, A.; Alsinet, C.; Savic, R.; Cabellos, L.; Toffanin, S.; Hoshida, Y.; Villanueva, A.; Minguez, B.; Newell, P.; Tsai, H.-W.; et al. Wnt-pathway activation in two molecular classes of hepatocellular carcinoma and experimental modulation by sorafenib. Clin. Cancer Res. 2012, 18, 4997-5007. [CrossRef]

32. Hanahan, D.; Weinberg, R.A. Hallmarks of cancer: The next generation. Cell 2011, 144, 646-674. [CrossRef] [PubMed]

33. Sia, D.; Jiao, Y.; Martinez-Quetglas, I.; Kuchuk, O.; Villacorta-Martin, C.; Castro de Moura, M.; Putra, J.; Camprecios, G.; Bassaganyas, L.; Akers, N.; et al. Identification of an Immune-specific Class of Hepatocellular Carcinoma, Based on Molecular Features. Gastroenterology 2017, 153, 812-826. [CrossRef] [PubMed]

34. Zhang, B.-H.; Yang, B.-H.; Tang, Z.-Y. Randomized controlled trial of screening for hepatocellular carcinoma. J. Cancer Res. Clin. Oncol. 2004, 130, 417-422. [CrossRef] [PubMed] 
35. Singal, A.G.; Pillai, A.; Tiro, J. Early detection, curative treatment, and survival rates for hepatocellular carcinoma surveillance in patients with cirrhosis: A meta-analysis. PLoS Med. 2014, 11, e1001624. [CrossRef] [PubMed]

36. Yang, J.D.; Mannalithara, A.; Piscitello, A.J.; Kisiel, J.B.; Gores, G.J.; Roberts, L.R.; Kim, W.R. Impact of surveillance for hepatocellular carcinoma on survival in patients with compensated cirrhosis. Hepatology 2018, 68, 78-88. [CrossRef]

37. Sarasin, F.P.; Giostra, E.; Hadengue, A. Cost-effectiveness of screening for detection of small hepatocellular carcinoma in western patients with Child-Pugh class A cirrhosis. Am. J. Med. 1996, 101, 422-434. [CrossRef]

38. Yang, H.-I.; Yuen, M.-F.; Chan, H.L.-Y.; Han, K.-H.; Chen, P.-J.; Kim, D.-Y.; Ahn, S.-H.; Chen, C.-J.; Wong, V.W.-S.; Seto, W.-K. Risk estimation for hepatocellular carcinoma in chronic hepatitis B (REACH-B): Development and validation of a predictive score. Lancet. Oncol. 2011, 12, 568-574. [CrossRef]

39. Singal, A.; Volk, M.L.; Waljee, A.; Salgia, R.; Higgins, P.; Rogers, M.A.M.; Marrero, J.A. Meta-analysis: Surveillance with ultrasound for early-stage hepatocellular carcinoma in patients with cirrhosis. Aliment. Pharmacol. Ther. 2009, 30, 37-47. [CrossRef]

40. Trevisani, F.; D’Intino, P.E.; Morselli-Labate, A.M.; Mazzella, G.; Accogli, E.; Caraceni, P.; Domenicali, M.; De Notariis, S.; Roda, E.; Bernardi, M. Serum alpha-fetoprotein for diagnosis of hepatocellular carcinoma in patients with chronic liver disease: Influence of HBsAg and anti-HCV status. J. Hepatol. 2001, 34, 570-575. [CrossRef]

41. Pelizzaro, F.; Cardin, R.; Penzo, B.; Pinto, E.; Vitale, A.; Cillo, U.; Russo, F.P.; Farinati, F. Liquid Biopsy in Hepatocellular Carcinoma: Where Are We Now? Cancers 2021, 13, 2274. [CrossRef]

42. Forner, A.; Reig, M.; Bruix, J. Hepatocellular carcinoma. Lancet 2018, 391, 1301-1314. [CrossRef]

43. Galle, P.R.; Forner, A.; Llovet, J.M.; Mazzaferro, V.; Piscaglia, F.; Raoul, J.L.; Schirmacher, P.; Vilgrain, V. EASL Clinical Practice Guidelines: Management of hepatocellular carcinoma. J. Hepatol. 2018, 69, 182-236. [CrossRef] [PubMed]

44. Matsui, O.; Kobayashi, S.; Sanada, J.; Kouda, W.; Ryu, Y.; Kozaka, K.; Kitao, A.; Nakamura, K.; Gabata, T. Hepatocelluar nodules in liver cirrhosis: Hemodynamic evaluation (angiography-assisted CT) with special reference to multi-step hepatocarcinogenesis. Abdom. Imaging 2011, 36, 264-272. [CrossRef] [PubMed]

45. Tremosini, S.; Forner, A.; Boix, L.; Vilana, R.; Bianchi, L.; Reig, M.; Rimola, J.; Rodríguez-Lope, C.; Ayuso, C.; Solé, M.; et al Prospective validation of an immunohistochemical panel (glypican 3, heat shock protein 70 and glutamine synthetase) in liver biopsies for diagnosis of very early hepatocellular carcinoma. Gut 2012, 61, 1481-1487. [CrossRef] [PubMed]

46. Bruix, J.; Reig, M.; Sherman, M. Evidence-Based Diagnosis, Staging, and Treatment of Patients With Hepatocellular Carcinoma. Gastroenterology 2016, 150, 835-853. [CrossRef]

47. A new prognostic system for hepatocellular carcinoma: A retrospective study of 435 patients: The Cancer of the Liver Italian Program (CLIP) investigators. Hepatology 1998, 28, 751-755. [CrossRef]

48. Yau, T.; Tang, V.Y.F.; Yao, T.-J.; Fan, S.-T.; Lo, C.-M.; Poon, R.T.P. Development of Hong Kong Liver Cancer staging system with treatment stratification for patients with hepatocellular carcinoma. Gastroenterology 2014, 146, 1691-1700.e3. [CrossRef]

49. Llovet, J.M.; Brú, C.; Bruix, J. Prognosis of hepatocellular carcinoma: The BCLC staging classification. Semin. Liver Dis. 1999, 19, 329-338. [CrossRef]

50. Child, C.G.; Turcotte, J.G. Surgery and portal hypertension. Major Probl. Clin. Surg. 1964, 1, 1-85.

51. Ikai, I.; Arii, S.; Kojiro, M.; Ichida, T.; Makuuchi, M.; Matsuyama, Y.; Nakanuma, Y.; Okita, K.; Omata, M.; Takayasu, K.; et al Reevaluation of prognostic factors for survival after liver resection in patients with hepatocellular carcinoma in a Japanese nationwide survey. Cancer 2004, 101, 796-802. [CrossRef]

52. Llovet, J.M.; Peña, C.E.A.; Lathia, C.D.; Shan, M.; Meinhardt, G.; Bruix, J. Plasma biomarkers as predictors of outcome in patients with advanced hepatocellular carcinoma. Clin. Cancer Res. 2012, 18, 2290-2300. [CrossRef] [PubMed]

53. Novikova, M.V.; Khromova, N.V.; Kopnin, P.B. Components of the hepatocellular carcinoma microenvironment and their role in tumor progression. Biochemistry 2017, 82, 861-873. [CrossRef] [PubMed]

54. Qin, W.; Cao, Z.-Y.; Liu, S.-Y.; Xu, X.-D. Recent advances regarding tumor microenvironment and immunotherapy in hepatocellular carcinoma. Hepatoma Res. 2020, 6, 24. [CrossRef]

55. Tsuchida, T.; Friedman, S.L. Mechanisms of hepatic stellate cell activation. Nat. Rev. Gastroenterol. Hepatol. 2017, 14, 397-411. [CrossRef]

56. Schwabe, R.F.; Bataller, R.; Brenner, D.A. Human hepatic stellate cells express CCR5 and RANTES to induce proliferation and migration. Am. J. Physiol. Gastrointest. Liver Physiol. 2003, 285, G949-G958. [CrossRef]

57. Wynn, T.A. Cellular and molecular mechanisms of fibrosis. J. Pathol. 2008, 214, 199-210. [CrossRef]

58. Forbes, S.J.; Parola, M. Liver fibrogenic cells. Best Pract. Res. Clin. Gastroenterol. 2011, 25, 207-217. [CrossRef]

59. Faouzi, S.; Lepreux, S.; Bedin, C.; Dubuisson, L.; Balabaud, C.; Bioulac-Sage, P.; Desmoulière, A.; Rosenbaum, J. Activation of cultured rat hepatic stellate cells by tumoral hepatocytes. Lab. Investig. 1999, 79, 485-493.

60. Lv, X.; Fang, C.; Yin, R.; Qiao, B.; Shang, R.; Wang, J.; Song, W.; He, Y.; Chen, Y. Agrin para-secreted by PDGF-activated human hepatic stellate cells promotes hepatocarcinogenesis in vitro and in vivo. Oncotarget 2017, 8, 105340-105355. [CrossRef]

61. Amann, T.; Bataille, F.; Spruss, T.; Mühlbauer, M.; Gäbele, E.; Schölmerich, J.; Kiefer, P.; Bosserhoff, A.-K.; Hellerbrand, C. Activated hepatic stellate cells promote tumorigenicity of hepatocellular carcinoma. Cancer Sci. 2009, 100, 646-653. [CrossRef]

62. Sancho-Bru, P.; Juez, E.; Moreno, M.; Khurdayan, V.; Morales-Ruiz, M.; Colmenero, J.; Arroyo, V.; Brenner, D.A.; Ginès, P.; Bataller, R. Hepatocarcinoma cells stimulate the growth, migration and expression of pro-angiogenic genes in human hepatic stellate cells. Liver Int. 2010, 30, 31-41. [CrossRef] [PubMed] 
63. Coulouarn, C.; Corlu, A.; Glaise, D.; Guénon, I.; Thorgeirsson, S.S.; Clément, B. Hepatocyte-stellate cell cross-talk in the liver engenders a permissive inflammatory microenvironment that drives progression in hepatocellular carcinoma. Cancer Res. 2012, 72, 2533-2542. [CrossRef] [PubMed]

64. Carloni, V.; Luong, T.V.; Rombouts, K. Hepatic stellate cells and extracellular matrix in hepatocellular carcinoma: More complicated than ever. Liver Int. 2014, 34, 834-843. [CrossRef] [PubMed]

65. Bárcena, C.; Stefanovic, M.; Tutusaus, A.; Martinez-Nieto, G.A.; Martinez, L.; García-Ruiz, C.; De Mingo, A.; Caballeria, J.; Fernandez-Checa, J.C.; Marí, M.; et al. Angiogenin secretion from hepatoma cells activates hepatic stellate cells to amplify a self-sustained cycle promoting liver cancer. Sci. Rep. 2015, 5, 7916. [CrossRef] [PubMed]

66. Lin, N.; Meng, L.; Lin, J.; Chen, S.; Zhang, P.; Chen, Q.; Lin, Y. Activated hepatic stellate cells promote angiogenesis in hepatocellular carcinoma by secreting angiopoietin-1. J. Cell. Biochem. 2020, 121, 1441-1451. [CrossRef]

67. Zhu, B.; Lin, N.; Zhang, M.; Zhu, Y.; Cheng, H.; Chen, S.; Ling, Y.; Pan, W.; Xu, R. Activated hepatic stellate cells promote angiogenesis via interleukin-8 in hepatocellular carcinoma. J. Transl. Med. 2015, 13, 365. [CrossRef]

68. Bergers, G.; Song, S. The role of pericytes in blood-vessel formation and maintenance. Neuro. Oncol. 2005, 7, 452-464. [CrossRef]

69. Iwahasi, S.; Rui, F.; Morine, Y.; Yamada, S.; Saito, Y.U.; Ikemoto, T.; Imura, S.; Shimada, M. Hepatic Stellate Cells Contribute to the Tumor Malignancy of Hepatocellular Carcinoma Through the IL-6 Pathway. Anticancer Res. 2020, 40, 743-749. [CrossRef]

70. Wen, Q.; Xu, C.; Zhou, J.; Liu, N.-M.; Cui, Y.-H.; Quan, M.-F.; Cao, J.-G.; Ren, K.-Q. 8-bromo-7-methoxychrysin suppress stemness of SMMC-7721 cells induced by co-culture of liver cancer stem-like cells with hepatic stellate cells. BMC Cancer 2019, 19, 224 . [CrossRef]

71. Chiyonobu, N.; Shimada, S.; Akiyama, Y.; Mogushi, K.; Itoh, M.; Akahoshi, K.; Matsumura, S.; Ogawa, K.; Ono, H.; Mitsunori, Y.; et al. Fatty Acid Binding Protein 4 (FABP4) Overexpression in Intratumoral Hepatic Stellate Cells within Hepatocellular Carcinoma with Metabolic Risk Factors. Am. J. Pathol. 2018, 188, 1213-1224. [CrossRef]

72. Huang, J.-L.; Fu, Y.-P.; Gan, W.; Liu, G.; Zhou, P.-Y.; Zhou, C.; Sun, B.-Y.; Guan, R.-Y.; Zhou, J.; Fan, J.; et al. Hepatic stellate cells promote the progression of hepatocellular carcinoma through microRNA-1246-ROR $\alpha$-Wnt/ $\beta$-Catenin axis. Cancer Lett. 2020, 476, 140-151. [CrossRef] [PubMed]

73. Azzariti, A.; Mancarella, S.; Porcelli, L.; Quatrale, A.E.; Caligiuri, A.; Lupo, L.; Dituri, F.; Giannelli, G. Hepatic stellate cells induce hepatocellular carcinoma cell resistance to sorafenib through the laminin-332/ $\alpha 3$ integrin axis recovery of focal adhesion kinase ubiquitination. Hepatology 2016, 64, 2103-2117. [CrossRef] [PubMed]

74. Seitz, T.; Freese, K.; Dietrich, P.; Thasler, W.E.; Bosserhoff, A.; Hellerbrand, C. Fibroblast Growth Factor 9 is expressed by activated hepatic stellate cells and promotes progression of hepatocellular carcinoma. Sci. Rep. 2020, 10, 4546. [CrossRef] [PubMed]

75. Mogler, C.; König, C.; Wieland, M.; Runge, A.; Besemfelder, E.; Komljenovic, D.; Longerich, T.; Schirmacher, P.; Augustin, H.G. Hepatic stellate cells limit hepatocellular carcinoma progression through the orphan receptor endosialin. EMBO Mol. Med. 2017, 9, 741-749. [CrossRef] [PubMed]

76. Kalluri, R.; Zeisberg, M. Fibroblasts in cancer. Nat. Rev. Cancer 2006, 6, 392-401. [CrossRef]

77. Shimoda, M.; Mellody, K.T.; Orimo, A. Carcinoma-associated fibroblasts are a rate-limiting determinant for tumour progression. Semin. Cell Dev. Biol. 2010, 21, 19-25. [CrossRef]

78. Lau, E.Y.T.; Lo, J.; Cheng, B.Y.L.; Ma, M.K.F.; Lee, J.M.F.; Ng, J.K.Y.; Chai, S.; Lin, C.H.; Tsang, S.Y.; Ma, S.; et al. Cancer-Associated Fibroblasts Regulate Tumor-Initiating Cell Plasticity in Hepatocellular Carcinoma through c-Met/FRA1/HEY1 Signaling. Cell Rep. 2016, 15, 1175-1189. [CrossRef]

79. Pietras, K.; Ostman, A. Hallmarks of cancer: Interactions with the tumor stroma. Exp. Cell Res. 2010, 316, 1324-1331. [CrossRef]

80. Jia, C.-C.; Wang, T.-T.; Liu, W.; Fu, B.-S.; Hua, X.; Wang, G.-Y.; Li, T.-J.; Li, X.; Wu, X.-Y.; Tai, Y.; et al. Cancer-associated fibroblasts from hepatocellular carcinoma promote malignant cell proliferation by HGF secretion. PLoS ONE 2013, 8, e63243. [CrossRef]

81. Liu, J.; Chen, S.; Wang, W.; Ning, B.-F.; Chen, F.; Shen, W.; Ding, J.; Chen, W.; Xie, W.-F.; Zhang, X. Cancer-associated fibroblasts promote hepatocellular carcinoma metastasis through chemokine-activated hedgehog and TGF- $\beta$ pathways. Cancer Lett. 2016, 379, 49-59. [CrossRef]

82. Zhang, Y.; Pan, Q.; Shao, Z. Extracellular vesicle-encapsulated microRNA-1228-3p from cancer-associated fibroblasts promotes the chemoresistance of hepatocellular carcinoma cells via PLAC8. Am. J. Physiol. Gastrointest. Liver Physiol. 2020, 319, G638. [CrossRef]

83. Yugawa, K.; Yoshizumi, T.; Mano, Y.; Itoh, S.; Harada, N.; Ikegami, T.; Kohashi, K.; Oda, Y.; Mori, M. Cancer-associated fibroblasts promote hepatocellular carcinoma progression through downregulation of exosomal miR-150-3p. Eur. J. Surg. Oncol. 2020, 47, 384-393. [CrossRef] [PubMed]

84. Wang, F.; Li, L.; Piontek, K.; Sakaguchi, M.; Selaru, F.M. Exosome miR-335 as a novel therapeutic strategy in hepatocellular carcinoma. Hepatology 2018, 67, 940-954. [CrossRef] [PubMed]

85. Zhou, Y.; Ren, H.; Dai, B.; Li, J.; Shang, L.; Huang, J.; Shi, X. Hepatocellular carcinoma-derived exosomal miRNA-21 contributes to tumor progression by converting hepatocyte stellate cells to cancer-associated fibroblasts. J. Exp. Clin. Cancer Res. 2018, 37, 324. [CrossRef]

86. Qian, B.-Z.; Pollard, J.W. Macrophage diversity enhances tumor progression and metastasis. Cell 2010, 141, 39-51. [CrossRef]

87. Gordon, S.; Taylor, P.R. Monocyte and macrophage heterogeneity. Nat. Rev. Immunol. 2005, 5, 953-964. [CrossRef]

88. Shirabe, K.; Mano, Y.; Muto, J.; Matono, R.; Motomura, T.; Toshima, T.; Takeishi, K.; Uchiyama, H.; Yoshizumi, T.; Taketomi, A.; et al. Role of tumor-associated macrophages in the progression of hepatocellular carcinoma. Surg. Today 2012, 42, 1-7. [CrossRef] 
89. Takai, H.; Ashihara, M.; Ishiguro, T.; Terashima, H.; Watanabe, T.; Kato, A.; Suzuki, M. Involvement of glypican-3 in the recruitment of M2-polarized tumor-associated macrophages in hepatocellular carcinoma. Cancer Biol. Ther. 2009, 8, 2329-2338. [CrossRef]

90. Fan, Q.-M.; Jing, Y.-Y.; Yu, G.-F.; Kou, X.-R.; Ye, F.; Gao, L.; Li, R.; Zhao, Q.-D.; Yang, Y.; Lu, Z.-H.; et al. Tumor-associated macrophages promote cancer stem cell-like properties via transforming growth factor-beta1-induced epithelial-mesenchymal transition in hepatocellular carcinoma. Cancer Lett. 2014, 352, 160-168. [CrossRef]

91. Gupta, D.K.; Singh, N.; Sahu, D.K. TGF- $\beta$ Mediated Crosstalk Between Malignant Hepatocyte and Tumor Microenvironment in Hepatocellular Carcinoma. Cancer Growth Metastasis 2014, 7, 1-8. [CrossRef]

92. Wan, S.; Zhao, E.; Kryczek, I.; Vatan, L.; Sadovskaya, A.; Ludema, G.; Simeone, D.M.; Zou, W.; Welling, T.H. Tumor-associated macrophages produce interleukin 6 and signal via STAT3 to promote expansion of human hepatocellular carcinoma stem cells. Gastroenterology 2014, 147, 1393-1404. [CrossRef] [PubMed]

93. Roderfeld, M.; Rath, T.; Lammert, F.; Dierkes, C.; Graf, J.; Roeb, E. Innovative immunohistochemistry identifies MMP-9 expressing macrophages at the invasive front of murine HCC. World J. Hepatol. 2010, 2, 175-179. [CrossRef] [PubMed]

94. Fujita, N.; Nishie, A.; Aishima, S.; Kubo, Y.; Asayama, Y.; Ishigami, K.; Kakihara, D.; Ushijima, Y.; Takayama, Y.; Shirabe, K.; et al. Role of tumor-associated macrophages in the angiogenesis of well-differentiated hepatocellular carcinoma: Pathologicalradiological correlation. Oncol. Rep. 2014, 31, 2499-2505. [CrossRef] [PubMed]

95. Wang, B.; Li, Q.; Qin, L.; Zhao, S.; Wang, J.; Chen, X. Transition of tumor-associated macrophages from MHC class II(hi) to MHC class II(low) mediates tumor progression in mice. BMC Immunol. 2011, 12, 43. [CrossRef] [PubMed]

96. Arvanitakis, K.; Koletsa, T.; Mitroulis, I.; Germanidis, G. Tumor-Associated Macrophages in Hepatocellular Carcinoma Pathogenesis, Prognosis and Therapy. Cancers 2022, 14, 226. [CrossRef]

97. Yang, Y.; Ye, Y.-C.; Chen, Y.; Zhao, J.-L.; Gao, C.-C.; Han, H.; Liu, W.-C.; Qin, H.-Y. Crosstalk between hepatic tumor cells and macrophages via Wnt/ $\beta$-catenin signaling promotes M2-like macrophage polarization and reinforces tumor malignant behaviors. Cell Death Dis. 2018, 9, 793. [CrossRef]

98. Sprinzl, M.F.; Reisinger, F.; Puschnik, A.; Ringelhan, M.; Ackermann, K.; Hartmann, D.; Schiemann, M.; Weinmann, A.; Galle, P.R.; Schuchmann, M.; et al. Sorafenib perpetuates cellular anticancer effector functions by modulating the crosstalk between macrophages and natural killer cells. Hepatology 2013, 57, 2358-2368. [CrossRef]

99. Chen, J.; Li, G.; Meng, H.; Fan, Y.; Song, Y.; Wang, S.; Zhu, F.; Guo, C.; Zhang, L.; Shi, Y. Upregulation of B7-H1 expression is associated with macrophage infiltration in hepatocellular carcinomas. Cancer Immunol. Immunother. 2012, 61, 101-108. [CrossRef]

100. Zong, Z.; Zou, J.; Mao, R.; Ma, C.; Li, N.; Wang, J.; Wang, X.; Zhou, H.; Zhang, L.; Shi, Y. M1 Macrophages Induce PD-L1 Expression in Hepatocellular Carcinoma Cells Through IL-1 $\beta$ Signaling. Front. Immunol. 2019, 10, 1643. [CrossRef]

101. Wu, K.; Kryczek, I.; Chen, L.; Zou, W.; Welling, T.H. Kupffer cell suppression of CD8+ T cells in human hepatocellular carcinoma is mediated by B7-H1/programmed death-1 interactions. Cancer Res. 2009, 69, 8067-8075. [CrossRef]

102. Fujii, H.; Kawada, N. Fibrogenesis in alcoholic liver disease. World J. Gastroenterol. 2014, 20, 8048-8054. [CrossRef] [PubMed]

103. Dudley, A.C. Tumor endothelial cells. Cold Spring Harb. Perspect. Med. 2012, 2, a006536. [CrossRef] [PubMed]

104. Davis, G.E.; Senger, D.R. Endothelial extracellular matrix: Biosynthesis, remodeling, and functions during vascular morphogenesis and neovessel stabilization. Circ. Res. 2005, 97, 1093-1107. [CrossRef] [PubMed]

105. Pralhad, T.; Madhusudan, S.; Rajendrakumar, K. Concept, mechanisms and therapeutics of angiogenesis in cancer and other diseases. J. Pharm. Pharmacol. 2003, 55, 1045-1053. [CrossRef]

106. Baluk, P.; Morikawa, S.; Haskell, A.; Mancuso, M.; McDonald, D.M. Abnormalities of basement membrane on blood vessels and endothelial sprouts in tumors. Am. J. Pathol. 2003, 163, 1801-1815. [CrossRef]

107. Von Marschall, Z.; Cramer, T.; Höcker, M.; Finkenzeller, G.; Wiedenmann, B.; Rosewicz, S. Dual mechanism of vascular endothelial growth factor upregulation by hypoxia in human hepatocellular carcinoma. Gut 2001, 48, 87-96. [CrossRef]

108. Kim, K.-R.; Moon, H.-E.; Kim, K.-W. Hypoxia-induced angiogenesis in human hepatocellular carcinoma. J. Mol. Med. 2002, 80, 703-714. [CrossRef]

109. Xiong, X.X.; Qiu, X.Y.; Hu, D.X.; Chen, X.Q. Advances in Hypoxia-Mediated Mechanisms in Hepatocellular Carcinoma. Mol. Pharmacol. 2017, 92, 246-255. [CrossRef]

110. Morse, M.A.; Sun, W.; Kim, R.; He, A.R.; Abada, P.B.; Mynderse, M.; Finn, R.S. The role of angiogenesis in hepatocellular carcinoma. Clin. Cancer Res. 2019, 25, 912-920. [CrossRef]

111. Yamaguchi, R.; Yano, H.; Iemura, A.; Ogasawara, S.; Haramaki, M.; Kojiro, M. Expression of vascular endothelial growth factor in human hepatocellular carcinoma. Hepatology 1998, 28, 68-77. [CrossRef]

112. Amini, A.; Masoumi Moghaddam, S.; Morris, D.L.; Pourgholami, M.H. The critical role of vascular endothelial growth factor in tumor angiogenesis. Curr. Cancer Drug Targets 2012, 12, 23-43. [CrossRef] [PubMed]

113. Poon, R.T.P.; Ho, J.W.Y.; Tong, C.S.W.; Lau, C.; Ng, I.O.L.; Fan, S.-T. Prognostic significance of serum vascular endothelial growth factor and endostatin in patients with hepatocellular carcinoma. Br. J. Surg. 2004, 91, 1354-1360. [CrossRef] [PubMed]

114. Li, X.M.; Tang, Z.Y.; Qin, L.X.; Zhou, J.; Sun, H.C. Serum vascular endothelial growth factor is a predictor of invasion and metastasis in hepatocellular carcinoma. J. Exp. Clin. Cancer Res. 1999, 18, 511-517. [PubMed]

115. Heldin, C.-H. Targeting the PDGF signaling pathway in tumor treatment. Cell Commun. Signal. 2013, 11, 97. [CrossRef] 
116. Zhu, K.; Pan, Q.; Zhang, X.; Kong, L.-Q.; Fan, J.; Dai, Z.; Wang, L.; Yang, X.-R.; Hu, J.; Wan, J.-L.; et al. MiR-146a enhances angiogenic activity of endothelial cells in hepatocellular carcinoma by promoting PDGFRA expression. Carcinogenesis 2013, 34, 2071-2079. [CrossRef]

117. Cao, Y.; Cao, R.; Hedlund, E.-M. R Regulation of tumor angiogenesis and metastasis by FGF and PDGF signaling pathways. $J$. Mol. Med. 2008, 86, 785-789. [CrossRef]

118. Imura, S.; Miyake, H.; Izumi, K.; Tashiro, S.; Uehara, H. Correlation of vascular endothelial cell proliferation with microvessel density and expression of vascular endothelial growth factor and basic fibroblast growth factor in hepatocellular carcinoma. $J$. Med. Investig. 2004, 51, 202-209. [CrossRef]

119. Bupathi, M.; Kaseb, A.; Janku, F. Angiopoietin 2 as a therapeutic target in hepatocellular carcinoma treatment: Current perspectives. Onco. Targets. Ther. 2014, 7, 1927-1932. [CrossRef]

120. Torimura, T.; Ueno, T.; Kin, M.; Harada, R.; Taniguchi, E.; Nakamura, T.; Sakata, R.; Hashimoto, O.; Sakamoto, M.; Kumashiro, R.; et al. Overexpression of angiopoietin-1 and angiopoietin-2 in hepatocellular carcinoma. J. Hepatol. 2004, 40, 799-807. [CrossRef]

121. He, Y.-F.; Wang, C.-Q.; Yu, Y.; Qian, J.; Song, K.; Sun, Q.-M.; Zhou, J. Tie2-Expressing Monocytes Are Associated with Identification and Prognoses of Hepatitis B Virus Related Hepatocellular Carcinoma after Resection. PLoS ONE 2015, 10, e0143657. [CrossRef]

122. Scholz, A.; Rehm, V.A.; Rieke, S.; Derkow, K.; Schulz, P.; Neumann, K.; Koch, I.; Pascu, M.; Wiedenmann, B.; Berg, T.; et al. Angiopoietin-2 serum levels are elevated in patients with liver cirrhosis and hepatocellular carcinoma. Am. J. Gastroenterol. 2007, 102, 2471-2481. [CrossRef] [PubMed]

123. Kuboki, S.; Shimizu, H.; Mitsuhashi, N.; Kusashio, K.; Kimura, F.; Yoshidome, H.; Ohtsuka, M.; Kato, A.; Yoshitomi, H.; Miyazaki, M. Angiopoietin-2 levels in the hepatic vein as a useful predictor of tumor invasiveness and prognosis in human hepatocellular carcinoma. J. Gastroenterol. Hepatol. 2008, 23, e157-e164. [CrossRef] [PubMed]

124. Yoshiji, H.; Kuriyama, S.; Noguchi, R.; Yoshii, J.; Ikenaka, Y.; Yanase, K.; Namisaki, T.; Kitade, M.; Uemura, M.; Masaki, T.; et al. Angiopoietin 2 displays a vascular endothelial growth factor dependent synergistic effect in hepatocellular carcinoma development in mice. Gut 2005, 54, 1768-1775. [CrossRef] [PubMed]

125. Villa, E.; Critelli, R.; Lei, B.; Marzocchi, G.; Cammà, C.; Giannelli, G.; Pontisso, P.; Cabibbo, G.; Enea, M.; Colopi, S.; et al Neoangiogenesis-related genes are hallmarks of fast-growing hepatocellular carcinomas and worst survival. Results from a prospective study. Gut 2016, 65, 861-869. [CrossRef]

126. Gao, L.; Ge, C.; Fang, T.; Zhao, F.; Chen, T.; Yao, M.; Li, J.; Li, H. ANGPTL2 promotes tumor metastasis in hepatocellular carcinoma. J. Gastroenterol. Hepatol. 2015, 30, 396-404. [CrossRef]

127. Ringelhan, M.; Pfister, D.; O'Connor, T.; Pikarsky, E.; Heikenwalder, M. The immunology of hepatocellular carcinoma. Nat. Immunol. 2018, 19, 222-232. [CrossRef]

128. Roderburg, C.; Wree, A.; Demir, M.; Schmelzle, M.; Tacke, F. The role of the innate immune system in the development and treatment of hepatocellular carcinoma. Hepatic Oncol. 2020, 7, HEP17. [CrossRef] [PubMed]

129. Wan, S.; Kuo, N.; Kryczek, I.; Zou, W.; Welling, T.H. Myeloid cells in hepatocellular carcinoma. Hepatology 2015, 62, 1304-1312. [CrossRef]

130. Barnes, T.A.; Amir, E. HYPE or HOPE: The prognostic value of infiltrating immune cells in cancer. Br. J. Cancer 2017, 117, 451-460. [CrossRef] [PubMed]

131. Kalathil, S.G.; Thanavala, Y. Natural Killer Cells and T Cells in Hepatocellular Carcinoma and Viral Hepatitis: Current Status and Perspectives for Future Immunotherapeutic Approaches. Cells 2021, 10, 1332. [CrossRef]

132. Bozward, A.G.; Warricker, F.; Oo, Y.H.; Khakoo, S.I. Natural Killer Cells and Regulatory T Cells Cross Talk in Hepatocellular Carcinoma: Exploring Therapeutic Options for the Next Decade. Front. Immunol. 2021, 12, 1493. [CrossRef] [PubMed]

133. Bruix, J.; Chan, S.L.; Galle, P.R.; Rimassa, L.; Sangro, B. Systemic treatment of hepatocellular carcinoma: An EASL position paper. J. Hepatol. 2021, 75, 960-974. [CrossRef] [PubMed]

134. Finn, R.S.; Qin, S.; Ikeda, M.; Galle, P.R.; Ducreux, M.; Kim, T.-Y.; Kudo, M.; Breder, V.; Merle, P.; Kaseb, A.O.; et al. Atezolizumab plus Bevacizumab in Unresectable Hepatocellular Carcinoma. N. Engl. J. Med. 2020, 382, 1894-1905. [CrossRef] [PubMed]

135. Herbst, R.S.; Soria, J.C.; Kowanetz, M.; Fine, G.D.; Hamid, O.; Gordon, M.S.; Sosman, J.A.; McDermott, D.F.; Powderly, J.D.; Gettinger, S.N.; et al. Predictive correlates of response to the anti-PD-L1 antibody MPDL3280A in cancer patients. Nature 2014, 515, 563-567. [CrossRef] [PubMed]

136. Wallin, J.J.; Bendell, J.C.; Funke, R.; Sznol, M.; Korski, K.; Jones, S.; Hernandez, G.; Mier, J.; He, X.; Hodi, F.S.; et al. Atezolizumab in combination with bevacizumab enhances antigen-specific T-cell migration in metastatic renal cell carcinoma. Nat. Commun. 2016, 7, 12624. [CrossRef] [PubMed]

137. Finn, R.S.; Ryoo, B.-Y.; Merle, P.; Kudo, M.; Bouattour, M.; Lim, H.Y.; Breder, V.; Edeline, J.; Chao, Y.; Ogasawara, S.; et al Pembrolizumab As Second-Line Therapy in Patients With Advanced Hepatocellular Carcinoma in KEYNOTE-240: A Randomized, Double-Blind, Phase III Trial. J. Clin. Oncol. 2020, 38, 193-202. [CrossRef]

138. Yau, T.; Park, J.W.; Finn, R.S.; Cheng, A.-L.; Mathurin, P.; Edeline, J.; Kudo, M.; Han, K.-H.; Harding, J.J.; Merle, P.; et al. CheckMate 459: A randomized, multi-center phase III study of nivolumab (NIVO) vs. sorafenib (SOR) as first-line (1L) treatment in patients (pts) with advanced hepatocellular carcinoma (aHCC). Ann. Oncol. 2019, 30, v874-v875. [CrossRef]

139. Lee, M.S.; Ryoo, B.-Y.; Hsu, C.-H.; Numata, K.; Stein, S.; Verret, W.; Hack, S.P.; Spahn, J.; Liu, B.; Abdullah, H.; et al. Atezolizumab with or without bevacizumab in unresectable hepatocellular carcinoma (GO30140): An open-label, multicentre, phase 1b study. Lancet Oncol. 2020, 21, 808-820. [CrossRef] 
140. Liu, L.; Cao, Y.; Chen, C.; Zhang, X.; McNabola, A.; Wilkie, D.; Wilhelm, S.; Lynch, M.; Carter, C. Sorafenib blocks the $\mathrm{RAF} / \mathrm{MEK} / \mathrm{ERK}$ pathway, inhibits tumor angiogenesis, and induces tumor cell apoptosis in hepatocellular carcinoma model PLC/PRF/5. Cancer Res. 2006, 66, 11851-11858. [CrossRef]

141. Wilhelm, S.M.; Carter, C.; Tang, L.; Wilkie, D.; McNabola, A.; Rong, H.; Chen, C.; Zhang, X.; Vincent, P.; McHugh, M.; et al. BAY 43-9006 exhibits broad spectrum oral antitumor activity and targets the RAF/MEK/ERK pathway and receptor tyrosine kinases involved in tumor progression and angiogenesis. Cancer Res. 2004, 64, 7099-7109. [CrossRef]

142. Feng, Y.-X.; Wang, T.; Deng, Y.-Z.; Yang, P.; Li, J.-J.; Guan, D.-X.; Yao, F.; Zhu, Y.-Q.; Qin, Y.; Wang, H.; et al. Sorafenib suppresses postsurgical recurrence and metastasis of hepatocellular carcinoma in an orthotopic mouse model. Hepatology 2011, 53, 483-492. [CrossRef] [PubMed]

143. Geng, Z.; Jha, R.K.; Li, B.; Chen, C.; Li, W.; Zheng, J.; Wang, L.; Huanchen, S. Sorafenib inhibition of hepatic stellate cell proliferation in tumor microenvironment of hepatocellular carcinoma: A study of the sorafenib mechanisms. Cell Biochem. Biophys. 2014, 69, 717-724. [CrossRef] [PubMed]

144. Iyer, R.V.; Maguire, O.; Kim, M.; Curtin, L.I.; Sexton, S.; Fisher, D.T.; Schihl, S.A.; Fetterly, G.; Menne, S.; Minderman, H. Dose-Dependent Sorafenib-Induced Immunosuppression Is Associated with Aberrant NFAT Activation and Expression of PD-1 in T Cells. Cancers 2019, 11, 681. [CrossRef] [PubMed]

145. Llovet, J.M.; Ricci, S.; Mazzaferro, V.; Hilgard, P.; Gane, E.; Blanc, J.-F.; de Oliveira, A.C.; Santoro, A.; Raoul, J.-L.; Forner, A.; et al Sorafenib in advanced hepatocellular carcinoma. N. Engl. J. Med. 2008, 359, 378-390. [CrossRef]

146. Cheng, A.-L.; Kang, Y.-K.; Chen, Z.; Tsao, C.-J.; Qin, S.; Kim, J.S.; Luo, R.; Feng, J.; Ye, S.; Yang, T.-S.; et al. Efficacy and safety of sorafenib in patients in the Asia-Pacific region with advanced hepatocellular carcinoma: A phase III randomised, double-blind, placebo-controlled trial. Lancet Oncol. 2009, 10, 25-34. [CrossRef]

147. Reig, M.; Torres, F.; Rodriguez-Lope, C.; Forner, A.; LLarch, N.; Rimola, J.; Darnell, A.; Ríos, J.; Ayuso, C.; Bruix, J. Early dermatologic adverse events predict better outcome in HCC patients treated with sorafenib. J. Hepatol. 2014, 61, 318-324. [CrossRef]

148. Rahmani, M.; Davis, E.M.; Bauer, C.; Dent, P.; Grant, S. Apoptosis induced by the kinase inhibitor BAY $43-9006$ in human leukemia cells involves down-regulation of Mcl-1 through inhibition of translation. J. Biol. Chem. 2005, 280, 35217-35227. [CrossRef]

149. Stefanovic, M.; Tutusaus, A.; Martinez-Nieto, G.A.; Bárcena, C.; De Gregorio, E.; Moutinho, C.; Barbero-Camps, E.; Villanueva, A.; Colell, A.; Marí, M.; et al. Targeting glucosylceramide synthase upregulation reverts sorafenib resistance in experimental hepatocellular carcinoma. Oncotarget 2016, 7, 8253-8267. [CrossRef]

150. Tutusaus, A.; Stefanovic, M.; Boix, L.; Cucarull, B.; Zamora, A.; Blasco, L.; de Frutos, P.G.; Reig, M.; Fernandez-Checa, J.C.; Marí, M.; et al. Antiapoptotic BCL-2 proteins determine sorafenib/regorafenib resistance and BH3-mimetic efficacy in hepatocellular carcinoma. Oncotarget 2018, 9, 16701-16717. [CrossRef]

151. Shimizu, S.; Takehara, T.; Hikita, H.; Kodama, T.; Tsunematsu, H.; Miyagi, T.; Hosui, A.; Ishida, H.; Tatsumi, T.; Kanto, T.; et al Inhibition of autophagy potentiates the antitumor effect of the multikinase inhibitor sorafenib in hepatocellular carcinoma. Int. J. Cancer 2012, 131, 548-557. [CrossRef]

152. Tai, W.-T.; Shiau, C.-W.; Chen, H.-L.; Liu, C.-Y.; Lin, C.-S.; Cheng, A.-L.; Chen, P.-J.; Chen, K.-F. Mcl-1-dependent activation of Beclin 1 mediates autophagic cell death induced by sorafenib and SC-59 in hepatocellular carcinoma cells. Cell Death Dis. 2013, 4, e485. [CrossRef] [PubMed]

153. Prieto-Domínguez, N.; Ordóñez, R.; Fernández, A.; Méndez-Blanco, C.; Baulies, A.; Garcia-Ruiz, C.; Fernández-Checa, J.C.; Mauriz, J.L.; González-Gallego, J. Melatonin-induced increase in sensitivity of human hepatocellular carcinoma cells to sorafenib is associated with reactive oxygen species production and mitophagy. J. Pineal Res. 2016, 61, 396-407. [CrossRef] [PubMed]

154. Cucarull, B.; Tutusaus, A.; Hernáez-Alsina, T.; García de Frutos, P.; Reig, M.; Colell, A.; Marí, M.; Morales, A. Antioxidants Threaten Multikinase Inhibitor Efficacy against Liver Cancer by Blocking Mitochondrial Reactive Oxygen Species. Antioxidants 2021, 10, 1336. [CrossRef] [PubMed]

155. Van Malenstein, H.; Dekervel, J.; Verslype, C.; Van Cutsem, E.; Windmolders, P.; Nevens, F.; van Pelt, J. Long-term exposure to sorafenib of liver cancer cells induces resistance with epithelial-to-mesenchymal transition, increased invasion and risk of rebound growth. Cancer Lett. 2013, 329, 74-83. [CrossRef] [PubMed]

156. Chow, A.K.-M.; Ng, L.; Lam, C.S.-C.; Wong, S.K.-M.; Wan, T.M.-H.; Cheng, N.S.-M.; Yau, T.C.-C.; Poon, R.T.-P.; Pang, R.W.-C. The Enhanced metastatic potential of hepatocellular carcinoma (HCC) cells with sorafenib resistance. PLoS ONE 2013, 8, e78675. [CrossRef]

157. Liang, Y.; Zheng, T.; Song, R.; Wang, J.; Yin, D.; Wang, L.; Liu, H.; Tian, L.; Fang, X.; Meng, X.; et al. Hypoxia-mediated sorafenib resistance can be overcome by EF24 through Von Hippel-Lindau tumor suppressor-dependent HIF-1 $\alpha$ inhibition in hepatocellular carcinoma. Hepatology 2013, 57, 1847-1857. [CrossRef]

158. Dong, N.; Shi, X.; Wang, S.; Gao, Y.; Kuang, Z.; Xie, Q.; Li, Y.; Deng, H.; Wu, Y.; Li, M.; et al. M2 macrophages mediate sorafenib resistance by secreting HGF in a feed-forward manner in hepatocellular carcinoma. Br. J. Cancer 2019, 121, 22-33. [CrossRef]

159. Matsui, J.; Funahashi, Y.; Uenaka, T.; Watanabe, T.; Tsuruoka, A.; Asada, M. Multi-kinase inhibitor E7080 suppresses lymph node and lung metastases of human mammary breast tumor MDA-MB-231 via inhibition of vascular endothelial growth factor-receptor (VEGF-R) 2 and VEGF-R3 kinase. Clin. Cancer Res. 2008, 14, 5459-5465. [CrossRef] 
160. Adachi, Y.; Matsuki, M.; Watanabe, H.; Takase, K.; Kodama, K.; Matsui, J.; Funahashi, Y.; Nomoto, K. Antitumor and Antiangiogenic Activities of Lenvatinib in Mouse Xenograft Models of Vascular Endothelial Growth Factor-Induced Hypervascular Human Hepatocellular Carcinoma. Cancer Investig. 2019, 37, 185-198. [CrossRef]

161. Hoshi, T.; Watanabe Miyano, S.; Watanabe, H.; Sonobe, R.M.K.; Seki, Y.; Ohta, E.; Nomoto, K.; Matsui, J.; Funahashi, Y. Lenvatinib induces death of human hepatocellular carcinoma cells harboring an activated FGF signaling pathway through inhibition of FGFR-MAPK cascades. Biochem. Biophys. Res. Commun. 2019, 513, 1-7. [CrossRef]

162. Kimura, T.; Kato, Y.; Ozawa, Y.; Kodama, K.; Ito, J.; Ichikawa, K.; Yamada, K.; Hori, Y.; Tabata, K.; Takase, K.; et al. Immunomodulatory activity of lenvatinib contributes to antitumor activity in the Hepa1-6 hepatocellular carcinoma model. Cancer Sci. 2018, 109, 3993-4002. [CrossRef] [PubMed]

163. Kudo, M.; Finn, R.S.; Qin, S.; Han, K.-H.; Ikeda, K.; Piscaglia, F.; Baron, A.; Park, J.-W.; Han, G.; Jassem, J.; et al. Lenvatinib versus sorafenib in first-line treatment of patients with unresectable hepatocellular carcinoma: A randomised phase 3 non-inferiority trial. Lancet 2018, 391, 1163-1173. [CrossRef]

164. Kodama, K.; Kawaoka, T.; Namba, M.; Uchikawa, S.; Ohya, K.; Morio, K.; Nakahara, T.; Murakami, E.; Yamauchi, M.; Hiramatsu, A.; et al. Correlation between Early Tumor Marker Response and Imaging Response in Patients with Advanced Hepatocellular Carcinoma Treated with Lenvatinib. Oncology 2019, 97, 75-81. [CrossRef] [PubMed]

165. Chuma, M.; Uojima, H.; Numata, K.; Hidaka, H.; Toyoda, H.; Hiraoka, A.; Tada, T.; Hirose, S.; Atsukawa, M.; Itokawa, N.; et al Early Changes in Circulating FGF19 and Ang-2 Levels as Possible Predictive Biomarkers of Clinical Response to Lenvatinib Therapy in Hepatocellular Carcinoma. Cancers 2020, 12, 293. [CrossRef]

166. Saeki, I.; Yamasaki, T.; Yamashita, S.; Hanazono, T.; Urata, Y.; Furutani, T.; Yokoyama, Y.; Oishi, T.; Maeda, M.; Kimura, T.; et al Early Predictors of Objective Response in Patients with Hepatocellular Carcinoma Undergoing Lenvatinib Treatment. Cancers 2020, 12, 779. [CrossRef]

167. Takahashi, A.; Moriguchi, M.; Seko, Y.; Shima, T.; Mitsumoto, Y.; Takashima, H.; Kimura, H.; Fujii, H.; Ishikawa, H.; Takaharu, Y.; et al. Early Tumor Shrinkage as a Predictive Factor for Outcomes in Hepatocellular Carcinoma Patients Treated with Lenvatinib: A Multicenter Analysis. Cancers 2020, 12, 754. [CrossRef]

168. Fu, R.; Jiang, S.; Li, J.; Chen, H.; Zhang, X. Activation of the HGF/c-MET axis promotes lenvatinib resistance in hepatocellular carcinoma cells with high c-MET expression. Med. Oncol. 2020, 37, 24. [CrossRef]

169. Strumberg, D.; Schultheis, B. Regorafenib for cancer. Expert Opin. Investig. Drugs 2012, 21, 879-889. [CrossRef]

170. Carr, B.I.; D’Alessandro, R.; Refolo, M.G.; Iacovazzi, P.A.; Lippolis, C.; Messa, C.; Cavallini, A.; Correale, M.; Di Carlo, A. Effects of low concentrations of regorafenib and sorafenib on human HCC cell AFP, migration, invasion, and growth in vitro. J. Cell. Physiol. 2013, 228, 1344-1350. [CrossRef]

171. Carr, B.I.; Cavallini, A.; Lippolis, C.; D'Alessandro, R.; Messa, C.; Refolo, M.G.; Tafaro, A. Fluoro-Sorafenib (Regorafenib) effects on hepatoma cells: Growth inhibition, quiescence, and recovery. J. Cell. Physiol. 2013, 228, 292-297. [CrossRef]

172. Han, R.; Li, S. Regorafenib delays the proliferation of hepatocellular carcinoma by inducing autophagy. Pharmazie 2018, 73, 218-222. [CrossRef] [PubMed]

173. Cucarull, B.; Tutusaus, A.; Subías, M.; Stefanovic, M.; Hernáez-Alsina, T.; Boix, L.; Reig, M.; de Frutos, P.G.; Marí, M.; Colell, A.; et al. Regorafenib alteration of the BCL-xL/MCL-1 ratio provides a therapeutic opportunity for BH3-mimetics in hepatocellular carcinoma models. Cancers 2020, 12, 332. [CrossRef] [PubMed]

174. Tsai, J.-J.; Pan, P.-J.; Hsu, F.-T. Regorafenib induces extrinsic and intrinsic apoptosis through inhibition of ERK/NF- $k B$ activation in hepatocellular carcinoma cells. Oncol. Rep. 2017, 37, 1036-1044. [CrossRef] [PubMed]

175. Liu, Y.-C.; Wu, R.-H.; Wang, W.-S. Regorafenib diminishes the expression and secretion of angiogenesis and metastasis associated proteins and inhibits cell invasion via NF-кB inactivation in SK-Hep1 cells. Oncol. Lett. 2017, 14, 461-467. [CrossRef]

176. Chen, W.; Yang, J.; Zhang, Y.; Cai, H.; Chen, X.; Sun, D. Regorafenib reverses HGF-induced sorafenib resistance by inhibiting epithelial-mesenchymal transition in hepatocellular carcinoma. FEBS Open Bio. 2019, 9, 335-347. [CrossRef]

177. Bruix, J.; Qin, S.; Merle, P.; Granito, A.; Huang, Y.-H.; Bodoky, G.; Pracht, M.; Yokosuka, O.; Rosmorduc, O.; Breder, V.; et al Regorafenib for patients with hepatocellular carcinoma who progressed on sorafenib treatment (RESORCE): A randomised, double-blind, placebo-controlled, phase 3 trial. Lancet 2017, 389, 56-66. [CrossRef]

178. Finn, R.S.; Merle, P.; Granito, A.; Huang, Y.-H.; Bodoky, G.; Pracht, M.; Yokosuka, O.; Rosmorduc, O.; Gerolami, R.; Caparello, C.; et al. Outcomes of sequential treatment with sorafenib followed by regorafenib for HCC: Additional analyses from the phase III RESORCE trial. J. Hepatol. 2018, 69, 353-358. [CrossRef]

179. Yakes, F.M.; Chen, J.; Tan, J.; Yamaguchi, K.; Shi, Y.; Yu, P.; Qian, F.; Chu, F.; Bentzien, F.; Cancilla, B.; et al. Cabozantinib (XL184), a novel MET and VEGFR2 inhibitor, simultaneously suppresses metastasis, angiogenesis, and tumor growth. Mol. Cancer Ther. 2011, 10, 2298-2308. [CrossRef]

180. Xiang, Q.; Chen, W.; Ren, M.; Wang, J.; Zhang, H.; Deng, D.Y.B.; Zhang, L.; Shang, C.; Chen, Y. Cabozantinib suppresses tumor growth and metastasis in hepatocellular carcinoma by a dual blockade of VEGFR2 and MET. Clin. Cancer Res. 2014, 20, 2959-2970. [CrossRef]

181. Kelley, R.K.; Verslype, C.; Cohn, A.L.; Yang, T.-S.; Su, W.-C.; Burris, H.; Braiteh, F.; Vogelzang, N.; Spira, A.; Foster, P.; et al. Cabozantinib in hepatocellular carcinoma: Results of a phase 2 placebo-controlled randomized discontinuation study. Ann. Oncol. 2017, 28, 528-534. [CrossRef] 
182. Abou-Alfa, G.K.; Meyer, T.; Cheng, A.L.; El-Khoueiry, A.B.; Rimassa, L.; Ryoo, B.Y.; Cicin, I.; Merle, P.; Chen, Y.H.; Park, J.W.; et al. Cabozantinib in patients with advanced and progressing hepatocellular carcinoma. N. Engl. J. Med. 2018, 379, 54-63. [CrossRef] [PubMed]

183. Brahmer, J.R.; Drake, C.G.; Wollner, I.; Powderly, J.D.; Picus, J.; Sharfman, W.H.; Stankevich, E.; Pons, A.; Salay, T.M.; McMiller, T.L.; et al. Phase I study of single-agent anti-programmed death-1 (MDX-1106) in refractory solid tumors: Safety, clinical activity, pharmacodynamics, and immunologic correlates. J. Clin. Oncol. 2010, 28, 3167-3175. [CrossRef] [PubMed]

184. El-Khoueiry, A.B.; Sangro, B.; Yau, T.; Crocenzi, T.S.; Kudo, M.; Hsu, C.; Kim, T.Y.; Choo, S.P.; Trojan, J.; Welling, T.H.; et al Nivolumab in patients with advanced hepatocellular carcinoma (CheckMate 040): An open-label, non-comparative, phase 1/2 dose escalation and expansion trial. Lancet 2017, 389, 2492-2502. [CrossRef]

185. Sangro, B.; Melero, I.; Wadhawan, S.; Finn, R.S.; Abou-Alfa, G.K.; Cheng, A.-L.; Yau, T.; Furuse, J.; Park, J.-W.; Boyd, Z.; et al. Association of inflammatory biomarkers with clinical outcomes in nivolumab-treated patients with advanced hepatocellular carcinoma. J. Hepatol. 2020, 73, 1460-1469. [CrossRef]

186. Kim, C.G.; Kim, C.; Yoon, S.E.; Kim, K.H.; Choi, S.J.; Kang, B.; Kim, H.R.; Park, S.-H.; Shin, E.-C.; Kim, Y.-Y.; et al. Hyperprogressive disease during PD-1 blockade in patients with advanced hepatocellular carcinoma. J. Hepatol. 2020, 74, 350-359. [CrossRef]

187. Yau, T.; Kang, Y.-K.; Kim, T.-Y.; El-Khoueiry, A.B.; Santoro, A.; Sangro, B.; Melero, I.; Kudo, M.; Hou, M.-M.; Matilla, A.; et al Efficacy and Safety of Nivolumab Plus Ipilimumab in Patients With Advanced Hepatocellular Carcinoma Previously Treated With Sorafenib. JAMA Oncol. 2020, 6, e204564. [CrossRef]

188. Zhu, A.X.; Finn, R.S.; Edeline, J.; Cattan, S.; Ogasawara, S.; Palmer, D.; Verslype, C.; Zagonel, V.; Fartoux, L.; Vogel, A.; et al. Pembrolizumab in patients with advanced hepatocellular carcinoma previously treated with sorafenib (KEYNOTE-224): A non-randomised, open-label phase 2 trial. Lancet. Oncol. 2018, 19, 940-952. [CrossRef]

189. Kudo, M.; Hatano, E.; Ohkawa, S.; Fujii, H.; Masumoto, A.; Furuse, J.; Wada, Y.; Ishii, H.; Obi, S.; Kaneko, S.; et al. Ramucirumab as second-line treatment in patients with advanced hepatocellular carcinoma: Japanese subgroup analysis of the REACH trial. $J$. Gastroenterol. 2017, 52, 494-503. [CrossRef]

190. Zhu, A.X.; Kang, Y.K.; Yen, C.J.; Finn, R.S.; Galle, P.R.; Llovet, J.M.; Assenat, E.; Brandi, G.; Pracht, M.; Lim, H.Y.; et al Ramucirumab after sorafenib in patients with advanced hepatocellular carcinoma and increased $\alpha$-fetoprotein concentrations (REACH-2): A randomised, double-blind, placebo-controlled, phase 3 trial. Lancet Oncol. 2019, 20, 282-296. [CrossRef]

191. Kudo, M.; Okusaka, T.; Motomura, K.; Ohno, I.; Morimoto, M.; Seo, S.; Wada, Y.; Sato, S.; Yamashita, T.; Furukawa, M.; et al Ramucirumab after prior sorafenib in patients with advanced hepatocellular carcinoma and elevated alpha-fetoprotein: Japanese subgroup analysis of the REACH-2 trial. J. Gastroenterol. 2020, 55, 627-639. [CrossRef]

192. Reig, M.; Forner, A.; Rimola, J.; Ferrer-Fábrega, J.; Burrel, M.; Garcia-Criado, A.; Kelley, R.K.; Galle, P.R.; Mazzaferro, V.; Salem, R.; et al. BCLC strategy for prognosis prediction and treatment recommendation Barcelona Clinic Liver Cancer (BCLC) staging system. The 2022 update. J. Hepatol. 2022. [CrossRef] 